\title{
Exploring the interrelationships between technological predictors and behavioral mediators in online tax filing: The moderating role of perceived risk
}

Muhammad Shakaib Akram, Aneela Malik, Mahmud Akhter Shareef and M. Awais Shakir Goraya

\begin{abstract}
This study investigates the interrelationships between technological predictors and behavioral mediators in explaining users' continuance intention for online tax filing. Building on information systems (IS) success and IS continuance literature, this study proposes an extended conceptual framework by adding perceived functional benefit (PFB) as mediating, perceived risk as moderating, and demographic characteristics as control variables. The data collected, through a web-based survey, from 409 users of e-tax services in an emerging economy are analyzed through covariance-based structural equation modeling. Results confirm that PFB, confirmation of expectation, and satisfaction are the major antecedents of continuance intention for e-tax filing. The study also finds the evidence for the indirect effects of IS success factors on continuance intention through such antecedents. In addition, results suggest that the relationships between PFB and satisfaction as well as between PFB and continuance intention are contingent on the users' levels of perceived risk. The study concludes with the useful implications for academicians and policymakers in the context of an emerging economy.
\end{abstract}

Keywords: Confirmation, continuance intention, e-tax filing, IS success, functional benefit

\section{Introduction}

The introduction of e-tax filing is an initiative of the e-government which denotes the use of information and communication technologies (ICTs), particularly Internet-based applications (Liang \& Lu, 2013; Rana \& Dwivedi, 2015). The IT led e-tax filing system gains momentum to ensure the access to and delivery of government information and services to citizens, business partners, employees, and other agencies and entities (Bélanger \& Carter, 2008; Rose, Persson, Heeager, \& Irani, 2015; Shan, Wang, Wang, Hao, \& Hua, 2011; Shareef, Archer, \& Dwivedi, 2015; United Nations, 2016). However, the success of e-government 
projects, such as e-tax filing, depends not only on ICTs but also on the citizens who are the ultimate beneficiaries of these projects (Venkatesh, Sykes, \& Venkatraman, 2014).

Realizing the significance of electronic channel, governments around the world are rapidly shifting toward e-tax filing to provide effective and efficient services to their users (DeLone \& McLean, 2016; Lallmahomed, Lallmahomed, \& Lallmahomed, 2017; Sá, Rocha, \& Pérez Cota, 2016; Stefanovic, Marjanovic, Delić, Culibrk, \& Lalic, 2016). In this Internet age, citizens are becoming more powerful in most of the countries as they can use various e-government services, such as filing of tax returns, applying for identity cards or driving license on their own through websites or mobile applications (DeLone \& McLean, 2016; Shareef et al., 2015; United Nations, 2016; Veeramootoo, Nunkoo, \& Dwivedi, 2018). In extending the aim of shifting powers to citizens, current governments provide various online services, including e-tax filing, which is a step toward taxpayers' empowerment (Bhuasiri, Zo, Lee, \& Ciganek, 2016; Schaupp, Carter, \& McBride, 2010).

The added services and the newly plugged in e-technologies have resonated the motivation and expectations of citizens in adapting governmental e-services (Carter, Weerakkody, Phillips, \& Dwivedi, 2016; Shareef et al., 2015). The integral gain of the e-tax filing system is to integrate all the processes involved, such as the preparation of tax documents, submission of tax returns, and the tax payment, at one point, over the web (Chaouali et al., 2016; Chen et al., 2015). E-tax filing helps improve the existing tax filing system while concurrently reduces the monetary cost for taxpayers and governments (Schaupp \& Carter, 2010; Veeramootoo et al., 2018).

Adoption and continuance being different concepts may not result from the same set of determinants (Bhattacherjee, 2001; Venkatesh, Thong, Chan, Hu, \& Brown, 2011). Continuance intention refers to users' post-adoption intention to continuously use a specific technology (Bhattacherjee, 2001; Nabavi, Taghavi-Fard, Hanafizadeh, \& Taghva, 2016). If citizens do not adopt and continuously take advantage of e-government services, then egovernment projects may fail, and taxpayers' money may be wasted (Lallmahomed et al., 2017). Nonetheless, most e-government research focuses on factors affecting citizens' attitude toward online public services (Carter et al., 2016; Rana, Dwivedi, \& Williams, 2015; 
Shareef et al., 2011) and continuance intention toward e-government services, in general, yet e-tax filing is still in infancy (Santhanamery \& Ramayah, 2015; Veeramootoo et al., 2018). Historically, researchers borrowed constructs from technology adoption theories such as theory of reasoned action (TRA), theory of planned behavior (TPB), technology acceptance model (TAM), unified theory of acceptance and use of technology (UTAUT), and social cognitive theory to explore users' continuance intention (Nabavi et al., 2016; Venkatesh et al., 2011). Several researchers acknowledged the value of these theories and models in elucidating the initial adoption of information systems (Dwivedi, Shareef, Simintiras, Lal, \& Weerakkody, 2016). However, other researchers believed that such theories are not that suitable to underpin continuous usage behavior (Bhattacherjee, 2001; Veeramootoo et al., 2018). In extracting convincing points of view from the extant literature, Bhattacherjee (2001) argued that theories initially developed to explicate consumers' acceptance of information systems provide limited explanation of continuance user behavior.

To address the above identified research gap, this framework extends IS continuance (Bhattacherjee, 2001) and IS success (Delone \& McLean, 2003; DeLone \& McLean, 2016) models in the context of e-tax filing continuance intention by adding perceived functional benefit (Shareef et al., 2011) as a mediating; perceived risk as moderating; and demographics, such as age, gender, education, and e-tax filing experience as control variables. This research contributes to the e-tax filing continuance literature (Hu, Brown, Thong, Chan, \& Tam, 2009; Santhanamery \& Ramayah, 2015; Veeramootoo et al., 2018) by proposing an extended framework. The study is the first to formulate moderated mediation mechanism to examine whether the direct and indirect effects of PFB on continuance intention, through satisfaction, are moderated by perceived risk.

The review of extant literature on e-tax filing suggests that most recent research on e-tax filing is conducted from the perspective of developed countries (Carter, Shaupp, Hobbs, \& Campbell, 2011; Liang \& Lu, 2013; Schaupp et al., 2010). Only a few have investigated e-tax filing from the perspective of developing countries. (Chaouali, Yahia, Charfeddine, \& Triki, 2016; Chen, Jubilado, Capistrano, \& Yen, 2015; Fakhoury \& Aubert, 2015). This research attempts to respond to the recent calls for research on e-tax filing continuance from the perspective of developing countries (Lallmahomed et al., 2017; Rana, Dwivedi, \& Williams, 
2015). Therefore, this study also contributes to the literature on e-tax filing from the contextual perspective.

We find literature address e-tax filing continuance in the contexts of developing or emerging countries (Hu et al., 2009; Santhanamery \& Ramayah, 2015; Veeramootoo et al., 2018) but we cannot find studies in the context of sub-continent, especially Pakistan. Compared with other sub-continent countries, Pakistan has its own social, legal, environmental, political, and technological dynamics which affect its citizens' continuance intention toward e-tax filing. Thus, adopting the e-tax continuance model from another context may not fit with local conditions. Hence, this research enhances the limited understanding on e-tax filing continuance intention by theoretically developing and empirically testing an extended model for e-tax filing continuance from the perspective of developing counties.

In sum, this study aims to ascertain the antecedents of e-tax filing continuance and to explore the role of perceived risk on various relationships among PFB, satisfaction, and e-tax filing continuance intention. For the achievement of these objectives, the following questions are investigated in this study. (1) What are the major antecedents of e-tax filing continuance intention? (2) How do the relationships among PFB, satisfaction, and e-tax filing continuance intention depend upon the level of perceived risk? The proposed framework can be useful for academicians as it extends the debate regarding e-tax filing continuance in the context of emerging countries. Moreover, the implications can be beneficial for governments' IT practitioners who can develop their strategies to gain e-taxpayers' satisfaction and minimize their risk perceptions.

The rest of this paper is structured as follows: the first section is devoted to the literature review followed by the development of hypotheses, and conceptual model related to users' e-tax filing continuance intention. The second section covers the methodology, instrument design, research context, and sample. The third section elaborates on the analysis and the results. The final section comprises of the discussion, implications, limitations, future research, and conclusion. 


\section{Literature Review}

Technology acceptance and adoption are widely covered in the IS literature (Davis, 1989; Venkatesh, Morris, Davis, \& Davis, 2003) but the understanding of continuance intention for IS (Bhattacherjee, 2001; Venkatesh et al., 2014), in general, and citizens' continuance intention for e-tax filing, in particular, is still in its infancy (Hu et al., 2009; Santhanamery \& Ramayah, 2015; Veeramootoo et al., 2018). The acceptance and adoption of e-government services have been a topic of interest among IS researchers over past few decades (Dwivedi et al., 2016; Kurfal, Ali, Tokdemir, \& Paçin, 2017; Lin, Fofanah, \& Liang, 2011; Rana \& Dwivedi, 2015; Weerakkody, El-Haddadeh, \& Al-Shafi, 2011). Although several studies on the topic have been conducted in various countries (Carter et al., 2016; Gauld, Goldfinch, \& Horsburgh, 2010; Gupta, Dasgupta, \& Gupta, 2008; Kurfal et al., 2017; Shareef et al., 2011) yet limited studies focus on online tax adoption and continuance.

The extant research on e-tax filing is mainly grounded in various acceptance and adoption theories, such as TPB (Hung, Chang, \& Yu, 2006), TAM (Schaupp et al., 2010), UTAUT (Bhuasiri et al., 2016; Carter et al., 2011; Chaouali et al., 2016; Kurfal et al., 2017), IS success model (Chang, Li, Hung, \& Hwang, 2005; Chen et al., 2015; Veeramootoo et al., 2018), and expectation-confirmation model of IS continuance (ECM-ISC) (Hsu \& Chiu, 2004; Hu et al., 2009; Santhanamery \& Ramayah, 2015; Veeramootoo et al., 2018).

The theoretical foundation of this research is based on two widely accepted theories in ISECM-ISC (Bhattacherjee, 2001) and updated IS success model (Delone \& McLean, 2003). ECM-ISC advocates that confirmation stimulates satisfaction, and satisfaction arouses continuous intention among users, whereas IS success model supports the resonance of continuous intention due to its quality constructs, including information, system, and service quality (Veeramootoo et al., 2018). The proposed framework integrates the drivers of IS success from Delone \& McLean (2003) with the IS continuance characteristics from ECM-ISC to explain the continuance intention of e-tax filing.

ECM-ISC is a comprehensive framework to gauge IS continuance intention. However, ECMISC does not focus on the technical features of a successful IS, such as information, system, and service quality (Venkatesh et al., 2011). These characteristics play a crucial role, especially when there is no interaction between public service providers and citizens-in 
the context of e-tax filing-in developing users' positive attitude toward digital government services (DeLone \& McLean, 2016; Rana, Dwivedi, Williams, \& Weerakkody, 2015). In this context, features of website quality play an integral role in individuals' confirmation of expectation, $\mathrm{PFB}$, satisfaction, and continuance intention.

The analysis of past studies on e-tax filing shows that most of e-tax filing research has focused on users' acceptance or pre-adoption behavior (Bhuasiri et al., 2016; Carter, Shaupp, Hobbs, \& Campbell, 2011; Chaouali et al., 2016; Chen et al., 2015; Dorasamy, Marimuthu, Raman, \& Kaliannan, 2010; Floropoulos, Spathis, Halvatzis, \& Tsipouridou, 2010; Schaupp \& Carter, 2010). However, we find very limited studies on users' post-adoption behavior or continuance intention for e-tax filing (Hu et al., 2009; Santhanamery \& Ramayah, 2015; Veeramootoo et al., 2018). Base on decomposed TPB, Hsu and Chiu (2004) had proposed a conceptual model to explore e-service quality and continuance intention. They tested the model using data of 149 e-tax filers from Taiwan to examine their continuance usage intention of e-services. Their findings indicated that interpersonal influence, perceived usefulness, and perceived playfulness were the major drivers of e-service satisfaction which, along with users' internet self-efficacy, consequently resulted in e-service continuance. In a longitudinal study conducted in Hong Kong, Hu et al. (2009) examined the antecedents of etax payers service quality and continuance. The results suggested that security, convenience and perceived usefulness were the major drivers of service quality which consequently affected continuance intention. Santhanamery and Ramayah (2015) studied the roles of demographic and personality traits in e-tax filing continuance of Malaysian taxpayers. Their results suggested that personality traits, such as agreeableness, conscientiousness and openness significantly affected continuance intention. Moreover, a significant relationship existed between demographic variables and continuance intention. Recently, based on ECM and D\&M IS success model, Veeramootoo et al. (2018) proposed a conceptual model for measuring e-filing continuance usage. They tested their model with a data of 645 e-filing users from Mauritius. Their results suggested that users' e-filing continuance intention was subjective to the system quality, user satisfaction and habit while satisfaction had the strongest effect on e-tax file continuance. Table 1 provides an overview of e-tax filing studies. 
Table 1: Overview of studies on e-tax filing

\begin{tabular}{|c|c|c|c|c|}
\hline Author(s) & Country & $\begin{array}{l}\text { Major } \\
\text { Theories }\end{array}$ & $\begin{array}{l}\text { Dependent } \\
\text { Variable }\end{array}$ & Key Findings \\
\hline Wang (2002) & Taiwan & TAM & $\mathrm{BI}$ & $\begin{array}{l}\text { Computer self-efficacy affected PEOU, PU and } \\
\text { perceived credibility which in turn resulted in } \\
\text { users' adoption intention for e-tax-filing. }\end{array}$ \\
\hline $\begin{array}{l}\text { Wu \& Chen } \\
(2005)\end{array}$ & Taiwan & $\begin{array}{l}\text { TAM, } \\
\text { TPB, } \\
\text { Trust }\end{array}$ & $\begin{array}{l}\text { Adoption } \\
\text { intention }\end{array}$ & $\begin{array}{l}\text { By combining TAM and TPB with trust, a } \\
\text { conceptual model had been proposed to explain } \\
\text { users' e-tax filing intentions. The integrated } \\
\text { model significantly explained users' e-tax filing } \\
\text { intentions. }\end{array}$ \\
\hline $\begin{array}{l}\text { Hsu \& Chiu } \\
(2004)\end{array}$ & Taiwan & TPB & $\begin{array}{l}\text { E-service } \\
\text { continuanc } \\
\text { e }\end{array}$ & $\begin{array}{l}\text { Interpersonal influence, perceived usefulness, and } \\
\text { perceived playfulness were the major drivers of e- } \\
\text { service satisfaction which, along with users' } \\
\text { internet self-efficacy, consequently resulted in e- } \\
\text { service continuance. }\end{array}$ \\
\hline $\begin{array}{l}\text { Carter \& } \\
\text { Bélanger } \\
(2005)\end{array}$ & USA & TAM, DOI & $\begin{array}{l}\text { Intention to } \\
\text { Use }\end{array}$ & $\begin{array}{l}\text { Citizen's' intention to use an e-government } \\
\text { services was contingent on perceived ease of use } \\
\text { and compatibility. }\end{array}$ \\
\hline $\begin{array}{l}\text { Chang et al. } \\
(2005)\end{array}$ & Taiwan & $\begin{array}{l}\text { TAM, } \\
\text { D\&M IS } \\
\text { success } \\
\text { model } \\
\end{array}$ & $\mathrm{BI}$ & $\begin{array}{l}\text { Confirmed the role of information and system } \\
\text { quality along with perceived credibility as the } \\
\text { external variables. Validated TAM in the e-tax } \\
\text { filing context. }\end{array}$ \\
\hline $\begin{array}{l}\text { Fu et al. } \\
\text { (2006) }\end{array}$ & Taiwan & $\begin{array}{l}\text { TAM and } \\
\text { TPB }\end{array}$ & $\mathrm{BI}$ & $\begin{array}{l}\text { Usefulness created inclination in the taxpayers' } \\
\text { BI. Moreover, the perceived usefulness, subjective } \\
\text { norms and self-efficacy had varied effects among } \\
\text { manual and e-tax filers. }\end{array}$ \\
\hline $\begin{array}{l}\text { Hung et al. } \\
(2006)\end{array}$ & Taiwan & TPB & Intention & $\begin{array}{l}\text { Subjective norms, perceived behavioral control } \\
\text { and attitude were the significant predictors of e- } \\
\text { tax file intention. }\end{array}$ \\
\hline $\begin{array}{l}\text { Hu et al. } \\
\text { (2009) }\end{array}$ & $\begin{array}{l}\text { Hong } \\
\text { Kong }\end{array}$ & TAM & CIN & $\begin{array}{l}\text { Security, convenience and perceived usefulness } \\
\text { were the major drivers of service quality which } \\
\text { consequently affected CIN. }\end{array}$ \\
\hline Ojha (2009) & India & $\begin{array}{l}\text { TAM,TPB } \\
\text {,TRA, } \\
\text { UTAUT }\end{array}$ & $\mathrm{BI}$ & $\begin{array}{l}\text { Perceived ease-of-use, personal innovativeness, } \\
\text { relative advantage, performance of e-filing } \\
\text { service, and compatibility were the strong } \\
\text { predictors of BI. }\end{array}$ \\
\hline Chen (2010) & Taiwan & $\begin{array}{l}\text { D\&M IS } \\
\text { success } \\
\text { model }\end{array}$ & Satisfaction & $\begin{array}{l}\text { Information and system quality measure was } \\
\text { more integral than service quality measures in } \\
\text { translating taxpayers' satisfaction. }\end{array}$ \\
\hline $\begin{array}{l}\text { Dorasamy et } \\
\text { al. }(2010)\end{array}$ & Malaysia & TAM, DOI & $\mathrm{BI}$ & $\begin{array}{l}\text { Perceived readiness and convenience were the } \\
\text { dominant factors in using e-tax filing. }\end{array}$ \\
\hline $\begin{array}{l}\text { Floropoulos et } \\
\text { al. (2010) }\end{array}$ & Greece & $\begin{array}{l}\text { D\&M IS } \\
\text { Success } \\
\text { Model }\end{array}$ & Satisfaction & $\begin{array}{l}\text { Information, system and service quality } \\
\text { significantly influenced usefulness and } \\
\text { satisfaction while system quality had only a } \\
\text { significant effect on satisfaction. }\end{array}$ \\
\hline $\begin{array}{l}\text { Schaupp \& } \\
\text { Carter }(2010)\end{array}$ & USA & $\begin{array}{l}\text { Trust, } \\
\text { risk }\end{array}$ & $\begin{array}{l}\text { Intention to } \\
\text { use }\end{array}$ & $\begin{array}{l}\text { Trust, risk and optimism bias were the major } \\
\text { drivers of users' e-file intentions. }\end{array}$ \\
\hline $\begin{array}{l}\text { Schaupp et al. } \\
\text { (2010) }\end{array}$ & USA & $\begin{array}{l}\text { UTAUT, } \\
\text { TAM }\end{array}$ & $\begin{array}{l}\text { Intention to } \\
\text { use }\end{array}$ & $\begin{array}{l}\text { Performance expectancy, social influence, } \\
\text { optimism bias and perceived risk significantly } \\
\text { impacted e-filing intentions. }\end{array}$ \\
\hline
\end{tabular}




\begin{tabular}{|c|c|c|c|c|}
\hline Author(s) & Country & $\begin{array}{l}\text { Major } \\
\text { Theories }\end{array}$ & $\begin{array}{l}\text { Dependent } \\
\text { Variable }\end{array}$ & Key Findings \\
\hline $\begin{array}{l}\text { Carter et al. } \\
(2011)\end{array}$ & USA & UTAUT & $\begin{array}{l}\text { Intention to } \\
\text { Use }\end{array}$ & $\begin{array}{l}\text { UTAUT constructs were confirmed as predictors } \\
\text { of e-filing intentions. The study also stressed on } \\
\text { integration of UTAUT with other theories, such as } \\
\text { social cognition to further understand taxpayers' } \\
\text { e-file intentions. }\end{array}$ \\
\hline $\begin{array}{l}\text { Hussein et al. } \\
\text { (2011) }\end{array}$ & Malaysia & $\begin{array}{l}\text { TAM, } \\
\text { DOI, }\end{array}$ & $\begin{array}{l}\text { Intention to } \\
\text { Use }\end{array}$ & $\begin{array}{l}\text { PEOU, PU, trust of the government, image, } \\
\text { compatibility and service quality were the major } \\
\text { drivers of e-filing intention. }\end{array}$ \\
\hline $\begin{array}{l}\text { Chen et al. } \\
\text { (2015) }\end{array}$ & Philippine & $\begin{array}{l}\text { D\&M IS } \\
\text { Success } \\
\text { Model }\end{array}$ & $\begin{array}{l}\text { Perceived } \\
\text { net benefits }\end{array}$ & $\begin{array}{l}\text { Trust in e-government website was derived from } \\
\text { trust in technology and government in general as } \\
\text { well as prior experience. Trust in e-government } \\
\text { online system influenced three IS quality } \\
\text { dimensions which subsequently resulted in net } \\
\text { benefits. }\end{array}$ \\
\hline $\begin{array}{l}\text { Santhanamery } \\
\text { \& Ramayah } \\
\text { (2015) }\end{array}$ & Malaysia & $\begin{array}{l}\text { Personali } \\
\text { ty traits }\end{array}$ & CIN & $\begin{array}{l}\text { Personality traits, such as agreeableness, } \\
\text { conscientiousness and openness significantly } \\
\text { affected continuance intention. Moreover, a } \\
\text { significant relationship existed between } \\
\text { demographic variables and continuance intention. }\end{array}$ \\
\hline $\begin{array}{l}\text { Bhuasiri et al. } \\
\text { (2016) }\end{array}$ & Thailand & $\begin{array}{l}\text { UTAUT, } \\
\text { SDT, PCT }\end{array}$ & $\begin{array}{l}\text { Intention to } \\
\text { Use }\end{array}$ & $\begin{array}{l}\text { Performance expectancy, facilitating conditions, } \\
\text { social influence, and perceived credibility } \\
\text { emerged as the significant predictors of citizens' } \\
\text { intentions to adopt an e-tax filing. }\end{array}$ \\
\hline $\begin{array}{l}\text { Chaouali et al. } \\
\text { (2016) }\end{array}$ & Tunisia & UTAUT & $\begin{array}{l}\text { Behavioral } \\
\text { expectation }\end{array}$ & $\begin{array}{l}\text { Performance expectancy, effort expectancy, } \\
\text { aspects of social influences and trusting } \\
\text { dimensions significantly influenced behavioral } \\
\text { intention. }\end{array}$ \\
\hline $\begin{array}{l}\text { Veeramootoo } \\
\text { et al. (2018) }\end{array}$ & Mauritius & $\begin{array}{l}\text { ECM and } \\
\text { D\&M IS } \\
\text { success } \\
\text { model }\end{array}$ & CIN & $\begin{array}{l}\text { Users' e-filing continuance usage intention was } \\
\text { subjective to the system quality, user satisfaction } \\
\text { and habit while satisfaction had the strongest } \\
\text { effect on e-tax file continuance. }\end{array}$ \\
\hline
\end{tabular}

Note: UTAUT= Unified Theory of Acceptance and Use of Technology, TAM= Technology Acceptance Model, TPB= Theory of Planned Behavior, DOI= Diffusion of Innovation, TRI: Technology Readiness Index, SDT: Self-Determination theory, perceived risk, and perceived credibility, SCT=social cognitive theory, SNCT= social norms and contingency theory, PCT: Perceived Credibility Theory, CINT: Continuance Intention, BI: Behavioral Intention

In the following section, we discuss the formulation and substantiation of hypotheses for developing the conceptual model (Figure 1) of this study.

\section{Hypotheses and Conceptual Model Development}

\section{ECM-ISC}

Building on the information systems (Davis, 1989) and consumer behavior research, Bhattacherjee (2001) proposed ECM-ISC to explain individuals' continuance intentions for IS. Such an intention is individuals' intent and motivation to reuse IS in the future (Bhattacherjee, 2001) and in the case of tax filing, taxpayers' intention to reuse e-tax filing system. Continuance intention for information technology has been a topic of interest among 
IS researchers (Bhattacherjee, 2001; Stefanovic et al., 2016; Venkatesh et al., 2014). ECM-ISC reveals that users' IS continuance intention is contingent on their satisfaction and perceived usefulness. Moreover, perceived usefulness and satisfaction are influenced by their confirmation of expectation from their past usage.

Over the past decade, ECM-ISC has emerged as a strong theoretical foundation to explain IS continuance of emerging technologies. ECM-ISC focuses on the post usage behavior of IS, and the model has been used, in various contexts, to explain users' IS continuance intention, such as social networking sites (Lin et al., 2017); cloud storage services (Yang \& Lin, 2015); virtual worlds (Zhou, Jin, \& Fang, 2014) etc. Wang (2014) applied the ECM-ISC framework to explore the perceived value of m-government continuance in China. He found mobility, security, and perceived values to be the predictors of perceived value, and consequently to the trust in the government/technology. However, only limited studies use the ECM-ISC framework to gauge e-tax continuance intention. Veeramootoo et al. (2018) presented an integrated model, in their study of e-filing continuance, based on the IS success model and expectancy confirmation model. They argued that system quality, user satisfaction, and habit were the significant predictors of e-filing continuance intention. Using a sample drawn from Malaysia, Santhanamery and Ramayah (2015) examined the role of demographic characteristics and personality traits on e-filing continuance usage intention. Hu et al. (2009) employed a longitudinal study to examine the continuance intention for e-tax filing services in Hong Kong. They suggested that service quality and perceived usefulness were the major determinants of continuance intention. These studies validate that ECM-ISC is a promising theory that examines post-adoption or continuance behavior. However, inconsistent findings in the extant literature, on e-filing continuance intention, call for further research on the topic in diversified contexts. Various ECM-ISC constructs and their relationships with respect to e-tax have been developed in the following section.

\section{Users' Satisfaction}

Users' satisfaction, which is individuals' evaluation of past positive or negative experience, is a standard measure of IS success (DeLone \& McLean, 2016) and continued intention (Bhattacherjee, 2001). DeLone and McLean (2003) considered user satisfaction as a longterm factor affecting individuals' use/intention to use and net benefits. In the e-government 
context, citizens' satisfaction reflects their pleasant experience due to the fulfillment of their routine tasks. Satisfaction, which is an integral byproduct of IS, creates inclination in the behavioral intent of users. Users' satisfaction with public services, such as e-tax filing, and their continuance intention to use these services assures the success of public services. Generally, satisfaction or dissatisfaction is understood as a result of past positive or negative experience (Porumbescu, 2016). User satisfaction is a fundamental construct in the IS success model and ECM-ISC (Bhattacherjee, 2001; Chou, Min, Chang, \& Lin, 2010). This study focuses on individuals' satisfaction with their experience related to the quality of egovernment websites along with their perceived usefulness and confirmation of experience. Many studies, based on ECM-ISC, have confirmed the significant positive effect of users' satisfaction on consumers' continuance intention for information technologies, in general (Hong, Tai, Hwang, Kuo, \& Chen, 2017) and e-tax filing continuance, in particular (Hsu \& Chiu, 2004; Veeramootoo et al., 2018).

Individuals' continuance intention, which is their commitment to post-adoption, is contingent on their satisfaction (Bhattacherjee, 2001). Citizens' prior experience with online channels plays an important role in forming their satisfaction levels. Therefore, the success/failure of these channels broadly depends upon citizens' satisfaction/dissatisfaction with the services and their continued usage of e-government platforms (Teo, Srivastava, \& Jiang, 2008). Research has affirmed a significant positive effect of citizens' satisfaction on their continuance intention for e-government (Hong et al., 2017; Sá et al., 2016). Therefore, we posit the following:

H1: Users' satisfaction with e-tax filing systems is positively associated with their continuance intention toward such systems.

\section{Functional Benefit}

Literature on technology acceptance establishes perceived usefulness as a strong factor in resonating user adoption and usage behavior (Davis, 1989). Similarly, perceived usefulness has been presented by DOI's construct for relative-advantage, which believes that perceived innovation is better than its precursor (Moore \& Benbasat, 1991). Venkatesh et al. (2003) used UTAUT to present performance expectancy as the antecedent of behavioral intention and subsequently of usage. They defined performance expectancy as the degree to which 
individuals believe that using systems can help them achieve specific benefits. In addition, they argued that perceived usefulness and relative advantage are related to performance expectancy (Venkatesh et al., 2003). By integrating these two factors, Shareef et al. (2011) introduced PFB as the predictor of e-government adoption, which they defined as "The degree to which citizens perceive the overall functional benefits, absolute and relativeincluding cost, time, efficiency, and effectiveness of using an e-government system-instead of using traditional government physical office," (p. 31). PFB encompasses multiple aspects, such as the behavioral and economic aspects of e-tax filing. Therefore, we employed PFB instead of perceived usefulness in the ECM-ISC model.

Citizens may find certain benefits in the e-tax filing system, which may help them save time and cost in performing various tasks compared with traditional paper-based tax filing (Bélanger \& Carter, 2008; Gilbert, Balestrini, \& Littleboy, 2004; Shareef et al., 2011). Adopting the e-tax filing systems makes citizens take advantage of relative benefits, such as effectiveness, availability, accessibility, and time/cost savings. We argue that high functional benefits can increase citizens' satisfaction and continuance intention for e-tax.

H2: Users' PFB from e-tax filing systems is positively related to their satisfaction with such systems.

H3: Users' PFB from e-tax filing systems is positively related to their continuance intention toward such systems.

\section{Confirmation of Expectation}

On the basis of ECM-ISC, user satisfaction is a consequence of their confirmation of expectation and the perceived usefulness of IS. Users develop their expectations from IS, and the confirmation of their expectations, resulting from their actual use, determines their satisfaction (Bhattacherjee, 2001). E-government users' confirmation of expectation is defined as the extent to which users receive their expected benefits by using e-government services. Literature shows that the confirmation helps in attaining positive effects on individuals' satisfaction and subsequently on their continuance intention (Bhattacherjee, 2001). Citizens' decision for e-tax usage is influenced by their initial expectations from e-tax websites and their actual post usage experience. After visiting online tax filing websites, the extent to which citizens' expectation are met can affect their PFB and satisfaction levels with 
online systems. Citizens' PFB and satisfaction can determine their likelihood of using the online tax filing system continually. Thus, the study formulates the following hypotheses.

H4: Users' confirmation of expectation from e-tax systems is positively associated with their PFB.

H5: Users' confirmation of expectation from e-tax filing systems is positively related to their satisfaction with such systems.

\section{IS Success Model}

IS success models by DeLone and McLean $(1992,2003)$ are a significant development toward IS success measurement. In their study of 1992, they set the basis of IS success theory by proposing a theoretical model. They argued that system and information quality indicate user satisfaction, resulting in individual and organizational impacts (DeLone \& McLean, 1992). They further proposed that the components in this IS success model are interrelated and interdependent (Floropoulos et al., 2010). Following the evaluation of several contributions to their initial model, DeLone and McLean proposed a 10-year update in 2003. In this updated model, along with system and information quality, they proposed the service quality of IS as the predictor of intentions to use and user satisfaction, resulting in a net benefit. In their latest monograph in this series, DeLone and McLean (2016) further extended the literature on IS success by identifying critical IS success drivers and guidelines for their measurement.

Several studies have empirically investigated various relationships among the measures of the IS success model in various fields (Wang, Wang, \& Liu, 2015). However, few studies integrate such relationships in the perspective of e-government websites, such as e-tax continuance intention (Stefanovic et al., 2016; Wang \& Liao, 2008). Sambasivan, Wemyss, and Rose (2010) extended DeLone and McLean's IS success model by adding constructs of trust, facilitating condition, and web design quality. Through their study, conducted in Malaysia, they found website design quality among other constructs to be strongly linked to users' intention and actual user behavior. Lee \& Chung (2009) conducted a study in Korea and used the modified IS success model of DeLone and McLean to investigate the determinants of trust and satisfaction in mobile banking. Contrary to the design quality of interface effect on customers' trust and satisfaction, they found significant effects of system 
and information quality on these constructs. To assess e-government success factors in Taiwan, Wang and Liao (2008) also adapted the IS success model and found significant support for all the postulated relationships except for the system quality and use.

These examples, from literature, reinforce the integration of DeLone and McLean's model with other relevant constructs to understand and explain IS success. DeLone and McLean (2016) verified that despite having several studies on IS success, consensus on the variables measuring IS success was still lacking. They argued that the "causes" of IS success were generally confused with the "outcome" which was a success itself. Moreover, they proposed information, system, and service quality among other causes or drivers of IS success.

While reporting the taxes, no physical interaction exists between citizens and government agents; thus, high-quality e-tax websites may play a critical role in lessening citizens' risk perceptions and forming their satisfaction, which subsequently results in their continuance intention to use e-government websites to fulfill their tasks. Government websites must provide high-quality information and services to citizens (Teo et al., 2008). Therefore, the success of such websites depends upon their quality in terms of their availability, information, and service. The quality experienced by citizens helps them retain their prior beliefs in the relative usefulness of websites.

The quality of governments' e-tax filing websites refers to citizens' overall evaluation of efficiency and effectiveness of its services. High-quality e-tax filing websites offer users with efficient services in terms of time, cost, and communication; whereas, the effectiveness may be seen from convenience, ease of information retrieval, and personalization. High-quality etax filing system facilitates citizens at each step of their relationship with the government and reinforces the perceived benefit of the system by bridging up the gap which was formed due to lack of face-to-face interaction. The diverse and heterogeneous users of public electronic services may reveal different levels of satisfaction toward such services depending upon their perceived quality of these websites in terms of service, information, and system. Realizing e-tax web facilities is contingent on citizens' satisfaction and their continued use of such facilities, Bhattacherjee (2001) affirmed that satisfaction toward e-government web services assessed citizens' psychosomatic state, which concerned their intellectual judgment of their experiences with web services. Upon receiving satisfactory experience with such 
government services, citizens' trust and support for government initiatives of exercising such services may improve. Factors contrary to satisfactory experience may instate a decline in the positive attitude toward government initiatives of creating e-services. In addition, Hong et al. (2017) argued that satisfactory experience with the interface and content of egovernment services offered played an important role in predicting citizens' continuous intention for e-government.

In line with the updated IS success model (Delone \& McLean, 2003) we have selected information, system, and service quality to study the success of e-tax systems. DeLone and McLean (2003) defined information quality in terms of its timeliness, accuracy, completeness, and relevance of IS. Moreover, the information quality of e-government websites, such as e-tax can be of high quality if it is relevant, complete, accurate, and up-todate. Information of e-government websites can also be measured in terms of the degree to which the needs of citizens regarding the accuracy, reliability, conciseness, and precision of information are fulfilled (Floropoulos et al., 2010). Literature shows a consensus on the critical attributes of information quality (Valaei \& Baroto, 2017). IS quality refers to the necessary characteristics of IS itself, such as flexibility of the system, stability, reliability, user-friendly interface, ease of use, response time, and security (Delone \& McLean, 2003; Floropoulos et al., 2010). The system quality of e-government websites refers to users' perception of websites' accessibly, availability, convenience, flexibility, and reliability (DeLone \& McLean, 2016). Finally, service quality refers to the overall expectation of consumers regarding various services, such as availability and readiness of services, safety of transactions, and individual attention (Delone \& McLean, 2003; Floropoulos et al., 2010). A high-perceived website quality of e-tax systems in the perspective of information, system, and service may lead to the confirmation of citizens' expectation and perceived benefit. These outcomes eventually lead to users' satisfaction and continuance intention. Thus, we posit the following:

H6: Perceived high quality of e-tax filing website dimensions (information, system, and service) positively influence (a) PFB and (b) confirmation of expectation. 
H7: E-tax filing websites' perceived quality dimension (i.e., information, system, and service) affects continuance intention directly and indirectly through confirmation of expectation, $P F B$, and satisfaction.

\section{Potential Moderator}

\section{Perceived Risk}

Risk denotes individuals' understanding of potential gains and losses (Pavlou, 2003). Risk cannot be measured objectively; thus, literature focuses on assessing users' perceived risk (Bélanger \& Carter, 2008; Schaupp et al., 2010). Perceived risk is a relevant component in the early stages of citizens' e-tax adoption because, at this stage, consumers are not much confident and aware of public services. Therefore, determining users perceive risk in declaring online tax returns and their willing to rely on e-tax websites to obtain and provide personal information is important. Online taxpayers may have concerns about privacy apprehensions and financial costs they incur because of the lack of protection of their confidential information. Literature highlights the negative association of users' perceived risk in e-tax systems and their willingness to interact with such online systems (Carter \& Bélanger, 2005; Schaupp et al., 2010).

Compared with paper-based tax filing, online tax filing is more prone to citizens' risk perceptions. Absence of face-to-face interaction, growing cyber-attacks, and involvement of individuals' financial information in e-tax filing have stimulated consumers' risk (Schaupp et al., 2010). Thus, citizens' perceived risk is relevant in examing their continuance intention toward e-tax filing. Several dimensions of perceived risk have been discussed in the literature, including financial, performance, psychological, physical, social, and time risks (Pavlou, 2003). Instead of focusing on a certain dimension, this research regards perceived risk as a global measure of potential uncertain negative outcomes from e-tax systems.

Citizens' growing risk perceptions due to frequent cyber-attacks has shattered citizens' confidence in public services. Under these circumstances, we must understand how governments should respond to the needs of citizens. The provision of psychological and financial benefits to citizens may help reduce their risks and lead to enhanced satisfaction and positive attitude toward government e-services. Citizens' PFB from e-tax filing may 
overcome their high-risk perceptions and help improve their satisfaction which will result in their continuance intention.

Although Literature provides enough support for the adverse effects of perceived risk on IS adoption yet little consideration to the moderating effects of perceived risk has been paid. The review of extant literature, on e-tax filing, reveals that perceived risk has been considered as a barrier to the e-tax filing behavior (Bhuasiri et al., 2016; Schaupp \& Carter, 2010; Veeramootoo et al., 2018). In addition, the literature supports the positive association among PFB, satisfaction, and IS adoption behavior. Furthermore, literature on IS continuance suggests the positive effects of satisfaction on continuance intention (Bhattacherjee, 2001; Venkatesh et al., 2011). However, literature on e-tax filing does not consider users' risk perceptions in these relations. This study argues that the relationships among users' PFB, satisfaction, and continuance intention are subject to users' level of perceived risk. Such relationships may reinforce on low perceived risk and may reduce due to high-risk perception.

Therefore, the effects of PFB on satisfaction/continuance intention may be different for the various levels of risk perceptions. Similarly, satisfaction may result in continuance intention differently at different levels of perceived risk. The following hypotheses have been proposed to explore the moderating effects of perceived risk:

H8a: Compared with high $P R$, low $P R$ strengthens the relationship between $P F B$ and satisfaction.

H8b: Compared with high $P R$, low PR strengthens the relationship between $P F B$ and continuance intention.

H8c: Compared with high PR, low PR strengthens the relationship between satisfaction and continuance intention.

\section{Control Variables}

Recent literature suggests contradictory results related to the impact of demographic characters on e-government usage (Gauld et al., 2010; Stefanovic et al., 2016; Venkatesh et al., 2014). For instance, Stefanovic et al. (2016) did not find any significant impact of gender, age, and income on intention to use. Contrary to this, with data from rural India, Venkatesh et al. (2014) empirically confirmed the impact of demographics, such as gender, education, 
and income on e-government portal usage. However, they did not find any significant impact of age on e-government portals. Therefore, this study incorporates citizens' demographics, such as "gender," "age," "education," and "previous experience" in the context of e-tax services, as covariates.

On the basis of the above theoretical background, the conceptual model (Figure 1) showing hypothesized direct and indirect relationships among independent and dependent variables has been proposed. The framework suggests that the quality dimensions of e-government websites positively affect PFB and confirmation of expectation, which in turn affect users' satisfaction that finally leads to the continuance intention of e-tax services. Moreover, individuals' demographics, such as gender, age, education, and past e-tax experience, have been incorporated as control variables.

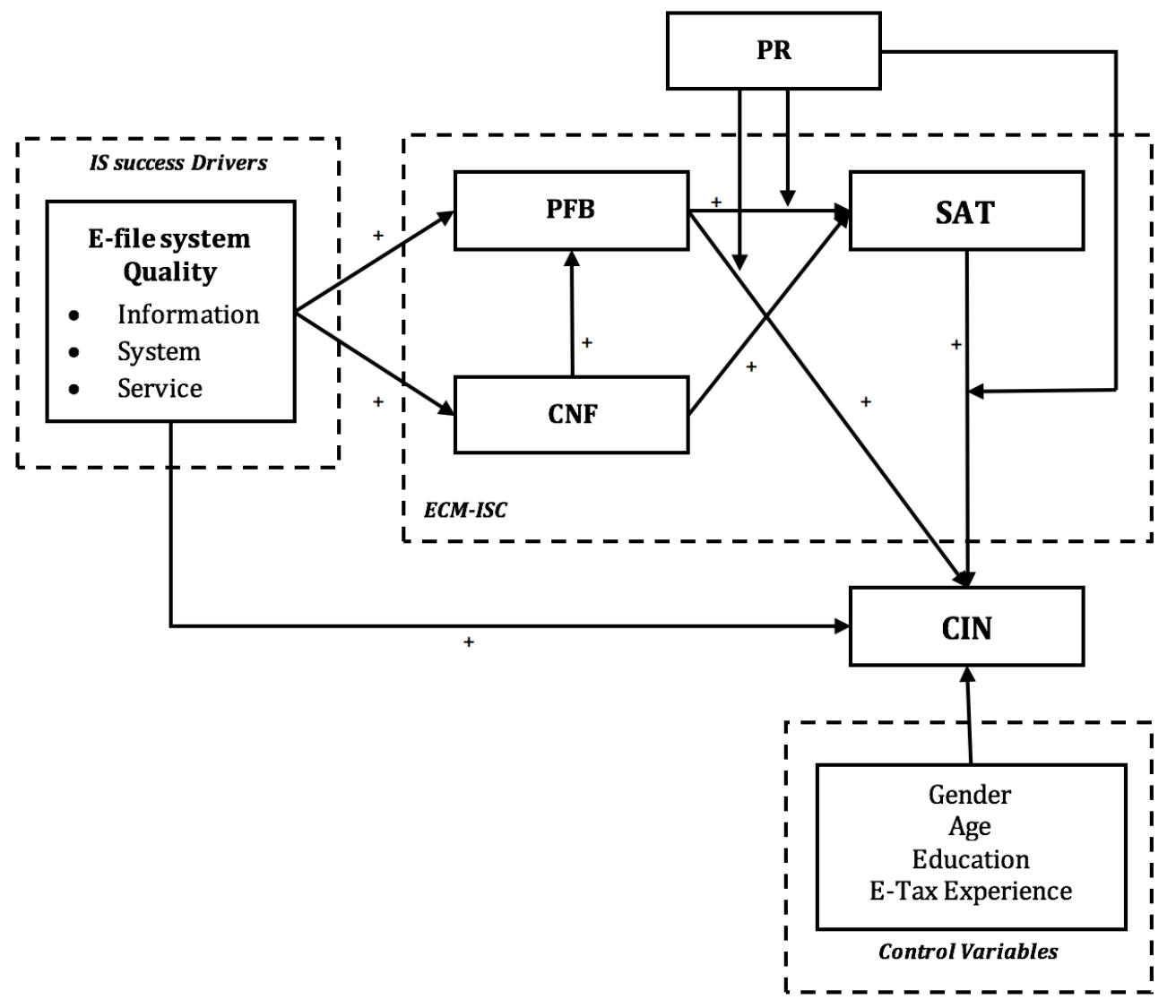

Note: $P F B=$ Perceived Functional benefit, $C N F=$ Confirmation of expectation, $P R=$ Perceived risk, SAT= Satisfaction, CIN= Continuance Intention

Figure 1: Conceptual Model 


\section{Method}

\section{Context}

To test the conceptual model, the data has been collected, through an online survey, targeted toward Pakistani taxpayers. In Pakistan, e-government services are emerging rapidly. According to the highlights of UN E-Government Survey (United Nations, 2016), Pakistan is grouped under the middle level of E-Government Development Index with an overall rank of 159. The government of Pakistan initiated e-services, in 2002, by establishing an Electronic Government Directorate (EGD). These days almost every public department, in Pakistan, has its website facilitating citizens in availing themselves of various online services. Citizens of Pakistan can apply online for various types of cards, such as National Identity Card (NID), Pakistan Origin Card (POC) and also Family Registration Certificate (FRC) through the online ID issuance system of National Database and Registration Authority (NADRA). They can receive the cards, at their homes, without visiting any government office. Likewise, citizens can also renew or extend the date of validity of their passport through the Directorate General of Immigration and Passports' online portal service from anywhere in the world. Along with these online services, citizens can also file their online tax returns through Federal Board of Revenue (FBR), Pakistan. This study is intended to investigate the e-tax continuance behavior of those Pakistani citizens who have certain experience with these services.

\section{Sample and procedure}

A brief introduction to the research was provided at the beginning of a structured questionnaire along with the links to the e-tax website to facilitate the respondents' understanding of the research. The respondents were contacted to participate in the survey during the tax return period. This helped the participants to share their fresh experience rather than imagining a hypothetical situation that they had not experienced. No personal information concerning respondents' identity was collected, and they were ensured that the data would be researched for the academic purposes only; moreover, their responses will remain confidential. At the beginning of the survey, the respondents were asked, whether they already had used the e-tax services and only those responses were considered, in the 
analysis, where the response was a 'yes' to this question. The questions were asked using the English language mainly due to three reasons: firstly, to retain the essence of the original scale; secondly, most of the e-government websites including e-tax (the field of this study) are currently available in the English language; thirdly, our respondents are the adopters of these services.

To have a representative sample, quotas for each province were assigned as per population distribution. Subsequently, the respondents were selected from the active taxpayer list available at FBR website (FBR, 2018). These respondents were briefed about the study, by telephone, and those having e-tax filing experience and a willingness to participate in the study were invited to participate in an online survey. Although more than one thousand invitations were sent to the potential respondents yet 582 completed surveys were received. We further eliminated 71 cases with atypical responses such as the responses from the participants who took too much (i.e., more than 15 minutes) or too little time (i.e., less than a minute) to complete the survey. Another 106 cases, having e-tax filing experience less than a year, were removed. The final sample of 409 consisted of $69.9 \%$ males and $30.1 \%$ females (Table 2).

Table 2: Sample Demographics

\begin{tabular}{llcc}
\hline Measure & Item & Frequency & Percentage \\
\hline Gender & Male & 286 & 69.9 \\
& Female & 123 & 30.1 \\
\hline \multirow{2}{*}{ Age } & Below 25 years & 70 & 17.1 \\
& 25 to 34 years & 203 & 49.6 \\
& 35 to 44 years & 110 & 26.9 \\
& 45 years and above & 26 & 6.4 \\
\hline Education & College degree and below & 143 & 35.0 \\
& Above college degree & 266 & 65.0 \\
\hline Internet usage & Less than 3 years & 29 & 7.1 \\
& 3 to 5 years & 51 & 12.5 \\
& More than 5 years & 329 & 80.4 \\
\hline E-tax experience & 1 to 2 years & 118 & 28.9 \\
& 2 to 3 years & 147 & 35.9 \\
& More than 3 years & 144 & 35.2 \\
\hline Occupation & Public Sector Employee & 124 & 30.3 \\
& Private Sector Employee & 135 & 33.0 \\
& Personal Business & 72 & 17.6 \\
& Other & 78 & 19.1 \\
\hline$N=409$ & & &
\end{tabular}

Majority of the respondents were between the ages of 25 to 34 years and had at least a college degree. All the respondents were regular internet users and a high proportion of the 
respondents (i.e., $80.4 \%$ ) had internet usage experience of more than five years. E-tax filing experience varied from less than two years (i.e., 28.9\%) to more than three years (i.e., $35.2 \%$ ). The sample consists of $30.3 \%$ public employees, $33 \%$ private sector employees and $17.6 \%$ entrepreneurs.

\section{Measurement}

To ensure the content validity of the scale, almost all the items have been adapted from the well-established literature as follows: quality measures from Stefanovic et al. (2016) and Wang \& Liao (2008); perceived risk from Carter \& Bélanger (2005) and Schaupp et al. (2010); functional benefit from Carter \& Bélange (2005); Shareef et al. (2011); Satisfaction, confirmation and continuance intention from (Bhattacherjee, 2001). All the latent constructs, in the survey, were measured using four items each except for confirmation of expectation which was measured by three items (see Appendix-A). These latent variables were measured on a 7-point Likert scale anchored between "strongly disagree" to "strongly agree."

To test the content and face validity of the instrument one focus group, sharing the similar demographics as of the main sample, was conducted. The participants were briefed on this research and consulted to make sure that the questionnaire actually measures the intended constructs in terms of clarity, formatting, relevance and language. Further, we selected 50 respondents from the population for the pre-testing of the instrument. This was followed by debriefing which refers to the discussion on the questions and related problems, with the respondents, after the questionnaire has been completed.

\section{Analysis and Results}

In view of our conceptual model, structural equation modeling has been used to evaluate the direct, indirect and interaction effects. In business research, the use of structural equation modeling has become quite prevalent due to its advantages of testing the measurement and the structural models thus allowing the researcher to test the psychometric properties of the scale and causal relationships (Hair, Wolfinbarger, Money, Samouel, \& Page, 2011). Covariance-based structural equation modeling (CB-SEM), having no limitation with respect to goodness of model fit measures, is a preferred technique for theory testing and 
confirmation as compared to less rigorous partial least squares approach (Kline, 2010). Thus, in this study, we have used CB-SEM for validating the measurement properties and testing the hypothesized relations. In this pursuit, conforming to the two-step for model testing by Anderson and Gerbing (1988), before testing the proposed hypotheses - through structural regression model - psychometric properties of the latent constructs have been assessed through the CB-SEM approach using AMOS 24. One of the assumptions of the covariance-based SEM procedures is multivariate normality. The skewness and kurtosis values for each of the items were analyzed and found to be under the acceptable range of -1 to 1 (Hair et al., 2011; Kline, 2010). However, coefficient of multivariate kurtosis value (Mardia's coefficient) shows a deviation from the normality assumption as its value is 118.843 with a critical ratio of 26.568 which is greater than the suggested value of 1.96 (Byrne, 2016). To address this issue boot-strapping has been employed (Kline, 2010).

\section{Psychometric properties}

A confirmatory factor analysis, together with all the latent constructs, was carried out to test the reliability and validity of the scale. An assessment of measurement model's goodness of fit indices indicate an adequate model fit as all the model fit measures $(\chi 2 / \mathrm{df}=1.439$; goodness of fit index $(\mathrm{GFI})=0.917$; comparative fit index $(\mathrm{CFI})=0.975$; Tucker-Lewis index $(\mathrm{TLI})=0.971$; root mean square error of approximation $($ RMSEA $)=0.033$; standardized root mean square residual $(S R M R)=0.037)$ were under the recommended levels $(L$. Hu \& Bentler, 1999).

While assessing the psychometric properties of the instrument, its reliability was assessed in terms of composite reliability $(\rho)$ and internal consistency $(\alpha)$; whereas, its validity was assessed by the convergent and the discriminant validity (Fornell \& Larcker, 1981; Henseler, Ringle, \& Sarstedt, 2015; Nunnally, 1978; Voorhees, Brady, Calantone, \& Ramirez, 2016). For the scale validity, $\alpha$ and $\rho$ values were assessed and found to be higher than 0.7 for all the constructs; thereby, establishing the reliability of the scale (Table 3).

The convergent validity can be evaluated through factor loadings and average variance extracted (Fornell \& Larcker, 1981). The factor loadings for each item of the eight formative constructs were significant at $\mathrm{p}<0.001$. In addition, the average variance extracted for each latent construct exceeded 0.5 ; thus, indicated the presence of convergent validity (Table 3 ). 
Generally in business and psychology research, Fornell and Larcker's (1981) criteria was used for testing discriminant validity. However, recently Henseler, Ringle, \& Sarstedt (2015) reasoned that the Heterotrait-monotrait (HTMT) ratios should be preferred as they prove better measure of discriminant validly as compared to the traditional Fornell and Larcker's (1981) criteria. Voorhees, Brady, Calantone, \& Ramirez (2016), proposed new guidelines for discriminant validity. They suggested that, for rigorous discriminant validity assessment, both Fornell and Larcker's (1981) (AVE>Shared variance) and Henseler et al.'s (2015) HTMT criteria (HTMT> 0.85) should be used simultaneously. Examination of HTMT values (Table 3) suggested that all the latent constructs in the measurement model were adequately discriminated as the HTMT values for each of the latent construct was below 0.85 (Henseler et al., 2015; Voorhees et al., 2016). Moreover, the evidence for discriminant validity was also established via Fornell and Larcker's (1981) criteria as the square root of AVE for each latent construct was higher than the inter-construct correlations (Table 3).

Table 3: Scale reliability and validity

\begin{tabular}{|c|c|c|c|c|c|c|c|c|c|c|c|}
\hline$\alpha$ & CR & AVE & Constructs & INQ & SYQ & SEQ & PFB & SAT & CNF & PR & CIN \\
\hline 0.867 & 0.867 & 0.619 & $\begin{array}{l}\text { Information Quality } \\
\text { (INQ) }\end{array}$ & 0.787 & 0.593 & 0.640 & 0.598 & 0.434 & 0.574 & 0.161 & 0.541 \\
\hline 0.849 & 0.850 & 0.587 & System Quality (SYQ) & 0.593 & 0.766 & 0.645 & 0.554 & 0.508 & 0.555 & 0.211 & 0.572 \\
\hline 0.822 & 0.822 & 0.537 & Service Quality (SEQ) & 0.634 & 0.644 & 0.733 & 0.612 & 0.475 & 0.577 & 0.143 & 0.567 \\
\hline 0.893 & 0.897 & 0.686 & $\begin{array}{l}\text { Perceived Functional } \\
\text { Benefit (PFB) }\end{array}$ & 0.607 & 0.559 & 0.611 & 0.828 & 0.675 & 0.701 & 0.249 & 0.774 \\
\hline 0.847 & 0.848 & 0.583 & Satisfaction (SAT) & 0.430 & 0.509 & 0.472 & 0.680 & 0.764 & 0.633 & 0.462 & 0.751 \\
\hline 0.813 & 0.815 & 0.595 & Confirmation (CNF) & 0.571 & 0.556 & 0.572 & 0.698 & 0.626 & 0.771 & 0.234 & 0.628 \\
\hline 0.809 & 0.809 & 0.516 & Perceived Risk (PR) & -0.164 & -0.214 & -0.137 & -0.254 & -0.471 & -0.239 & 0.718 & 0.358 \\
\hline 0.890 & 0.891 & 0.672 & $\begin{array}{l}\text { Continuance Intention } \\
\text { (CIN) }\end{array}$ & 0.545 & 0.564 & 0.565 & 0.778 & 0.747 & 0.622 & -0.371 & 0.820 \\
\hline
\end{tabular}

Note: Values in the diagonal are the square root of average variance extracted (AVE), below the diagonal are inter-construct correlations and above the diagonal are Heterotrait-Monotrait ratio (HTMT) of correlation, HTMT values have been calculated from SmartPLS 3.2, $\alpha=$ Cronbach's Alpha, $C R=$ Composite Reliability

\section{Common method variance}

There is a consensus, in behavioral research, on the possible issue of common method variance (CMV) which is the "variance that is attributable to the measurement method rather than to the constructs the measures represent" (Podsakoff, MacKenzie, Lee, \& Podsakoff, 2003, P. 879). Cross-sectional data collected from a single source for the causes and outcome 
variables - as is the case in this study - may probably lead to a common method bias which may result in inflated or deflated results (Podsakoff et al., 2003). There may be varied and complicated causes leading to CMV in survey design, thus there is no direct solution to fully address CMV issue (Guide \& Ketokivi, 2015; Podsakoff et al., 2003). To minimize the CMV, Guide and Ketokivi (2015) suggested this issue must be addressed right from the research design phase. Thus, to control CMV, multiple procedural and statistical remedies were applied. First, we used established scales, with high reliability measures, for each latent construct. Second, to avoid respondents' identity concerns and possible socially desirable response, the instrument did not include any items revealing respondent's identity. Moreover, respondents were assured of the anonymity of their responses. Third, Harman's single factor procedure has been used to see if a single factor explains the majority of variance (Podsakoff et al., 2003). An un-rotated factor solution with all the items in the study resulted in eight components explaining $68.539 \%$ cumulative variance with eigenvalues greater than 1 . However, the first component explained only $37.447 \%$ of variance which is significantly below the recommended criteria of 50\% (Podsakoff et al., 2003). Fourth, a confirmatory factor analysis was carried out by loading all the items to a single common factor. The results of single factor model measures $(\chi 2 / \mathrm{df}=6.530$; $\mathrm{GFI}=0.612 ; \mathrm{AGFI}=0.557$; $\mathrm{CFI}=0.657 ; \mathrm{TLI}=0.633 ; \mathrm{RMSEA}=0.116$; Standardized RMR $=0.096$ ) were much worse than the measurement model with eight latent constructs, indicating that a common factor is not a serious threat.

\section{Model testing}

After testing the psychometric properties of the scale, the structural model was used to assess direct, indirect and interaction effects in the conceptual model. We used the bootstrap procedure with maximum likelihood to calculate bias-corrected confidence intervals through AMOS 24. The assessment of the structural model fit resulted in $\chi^{2}$ value of 912.142 with 626 degrees of freedom. The normed $\chi^{2}$ was 1.457 which was quite below the recommended values of 3.0 (Hu \& Bentler, 1999). Other fit indices also adequately fulfilled the recommended criteria as the values of GFI $=0.899, \mathrm{CFI}=0.962, \mathrm{TLI}=0.957, \mathrm{RMSEA}=$ 0.033 and Standardized RMR $=0.061$ were all within the range for an acceptable model fit (Hu \& Bentler, 1999). 
Table 4 summarizes the standardized estimates for each direct effect in the structural model along with standard errors, bootstrap confidence intervals and two-tailed p-values. Majority of the proposed relationships are significantly supported. All the website quality dimensions have a significant positive effect on confirmation of expectation and PFB except for the effect of system quality on PFB. However, direct effects of quality dimensions on continuance intention are not significant.

Table 4: Structural model results (direct Effects)

\begin{tabular}{|c|c|c|c|c|c|}
\hline \multirow{2}{*}{ Relationship } & \multirow{2}{*}{$\begin{array}{c}\text { Std. } \\
\text { Estimate }\end{array}$} & \multirow{2}{*}{ SE } & \multicolumn{2}{|c|}{ Bootstrap Confidence intervals } & \multirow{2}{*}{ P-values } \\
\hline & & & Lower & Upper & \\
\hline $\mathrm{INQ} \rightarrow \mathrm{CNF}$ & 0.267 & 0.082 & 0.133 & 0.404 & 0.001 \\
\hline $\mathrm{SYQ} \rightarrow \mathrm{CNF}$ & 0.246 & 0.085 & 0.099 & 0.375 & 0.006 \\
\hline $\mathrm{SEQ} \rightarrow \mathrm{CNF}$ & 0.246 & 0.084 & 0.116 & 0.393 & 0.003 \\
\hline $\mathrm{INQ} \rightarrow \mathrm{PFB}$ & 0.188 & 0.076 & 0.064 & 0.311 & 0.018 \\
\hline $\mathrm{SYQ} \rightarrow \mathrm{PFB}$ & 0.088 & 0.086 & -0.051 & 0.230 & 0.310 \\
\hline $\mathrm{SEQ} \rightarrow \mathrm{PFB}$ & 0.187 & 0.080 & 0.058 & 0.317 & 0.017 \\
\hline $\mathrm{CNF} \rightarrow \mathrm{PFB}$ & 0.433 & 0.070 & 0.315 & 0.544 & 0.001 \\
\hline $\mathrm{CNF} \rightarrow \mathrm{SAT}$ & 0.290 & 0.083 & 0.146 & 0.420 & 0.001 \\
\hline $\mathrm{PFB} \rightarrow \mathrm{SAT}$ & 0.464 & 0.082 & 0.331 & 0.596 & 0.001 \\
\hline $\mathrm{PR} \rightarrow \mathrm{SAT}$ & -0.230 & 0.049 & -0.317 & -0.155 & 0.001 \\
\hline $\mathrm{PFB} \rightarrow \mathrm{CIN}$ & 0.438 & 0.075 & 0.308 & 0.556 & 0.001 \\
\hline $\mathrm{SAT} \rightarrow \mathrm{CIN}$ & 0.275 & 0.065 & 0.171 & 0.385 & 0.001 \\
\hline $\mathrm{PR} \rightarrow \mathrm{CIN}$ & -0.200 & 0.040 & -0.269 & -0.135 & 0.001 \\
\hline INQ $\rightarrow$ CIN & 0.054 & 0.061 & -0.047 & 0.154 & 0.348 \\
\hline $\mathrm{SYQ} \rightarrow \mathrm{CIN}$ & 0.081 & 0.064 & -0.023 & 0.188 & 0.206 \\
\hline $\mathrm{SEQ} \rightarrow \mathrm{CIN}$ & 0.068 & 0.075 & -0.052 & 0.197 & 0.321 \\
\hline Gender $\rightarrow$ CIN & 0.042 & 0.037 & -0.020 & 0.102 & 0.273 \\
\hline Education $\rightarrow$ CIN & -0.006 & 0.037 & -0.067 & 0.055 & 0.859 \\
\hline Age $1 \rightarrow$ CIN & 0.071 & 0.045 & -0.002 & 0.145 & 0.106 \\
\hline Age $2 \rightarrow$ CIN & 0.046 & 0.046 & -0.024 & 0.122 & 0.287 \\
\hline Age $2 \rightarrow$ CIN & -0.005 & 0.041 & -0.079 & 0.061 & 0.850 \\
\hline Exp1 $\rightarrow$ CIN & 0.090 & 0.042 & 0.023 & 0.162 & 0.032 \\
\hline $\operatorname{Exp} 2 \rightarrow \mathrm{CIN}$ & 0.071 & 0.045 & -0.001 & 0.149 & 0.108 \\
\hline
\end{tabular}

Note:

- INQ = Information Quality, SYQ=System Quality, SEQ=Service Quality, CNF= Confirmation of Expectation, PFB= Perceived Functional Benefit PR= Perceived Risk, SAT = Satisfaction, CIN= Continuance Intention, $P$-values are two-tailed significance

- Control variables are dummy coded, Gender $=[$ Male $=1$, Female $=0]$, Education $=[$ Colle and below $=0$, Above college $=1]$, Age $1=[25$ to 34 years $=1$, Otherwise $=0]$, Age $2=[35$ to 44 years $=0$, Otherwise $=0]$, Age $3=[45$ years and above $=1$, Otherwise $=0]$, Exp $1=[2$ to 3 years $=1$, Otherwise $=0]$, Exp $2=[$ More than 3 years $=1$, Otherwise $=0]$ 


\section{Mediating effects}

Hypothesis 7 posits the direct and indirect effects of e-tax website quality dimensions (i.e., information, system, and service) on continuance intention through confirmation of expectation, PFB and satisfaction. Direct effects of the quality dimensions on continuance intention information are presented in Table 4 and Table 5 provides total indirect effects along with standard errors, bootstrap confidence intervals and p-values. All the direct effects are not significant while the total indirect effects are significant this shows that the relationship between quality dimensions and continuance intention is fully mediated by the intervening variables i.e., confirmation of expectations, PFB, satisfaction. Specific indirect effects were also calculated to further explore the effects of quality dimensions on continuance intention though each indirect path (see Appendix B).

Table 5: Total indirect effects

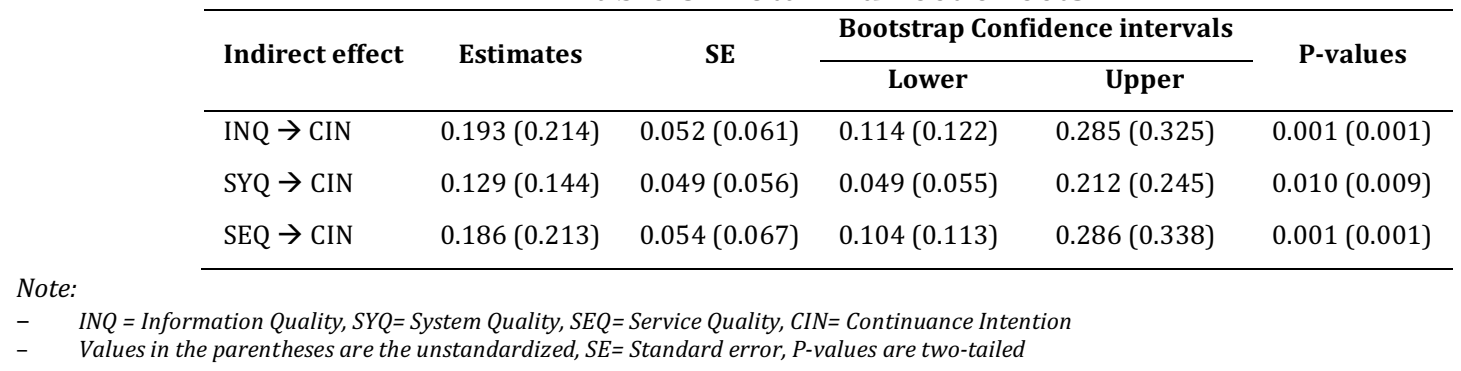

\section{Moderating effects}

In Hypothesis $\mathrm{H} 8 \mathrm{a}, \mathrm{b}, \mathrm{c}$, it was hypothesized that perceived risk moderate the pathways among functional benefit and satisfaction; functional benefit and continuance intention; and satisfaction and continuance intention. To estimate such moderated mediation effects, we used Process macro for SPSS (Model 59) which allows measurement of such moderated mediation effects and is less affected by the sample size (Hayes, 2013). Control variables were also included as covariates in the estimation. The results of the procedure (Table 6) indicate that PFB significantly effects Satisfaction $(b=0.537, p<0.0001)$ and this effect is moderated by Perceived Risk $(b=-0.181, p<0.001)$. Similarly, PFB significantly effects Continuance Intention $(b=0.482, p<0.0001)$ and this effect is moderated by Perceived Risk $(b=-0.125, p<0.01)$. However, the moderating effect of Perceived Risk on the relationship 
between Satisfaction and continuance Intention is not significant. Figure 2 to 4 , further illustrate the moderating effects of Perceived Risk.

Table 6: Moderating effect of Perceived Risk

\begin{tabular}{|c|c|c|c|c|c|c|c|c|c|c|}
\hline \multirow[t]{2}{*}{ Predictors } & \multicolumn{5}{|c|}{ Outcome (SAT) } & \multicolumn{5}{|c|}{ Outcome (CIN) } \\
\hline & $b$ & se & $t$ & $L L C I$ & $U L C I$ & $b$ & se & $t$ & $L L C I$ & ULCI \\
\hline Constant & $-0.268^{* *}$ & 0.124 & -2.161 & -0.512 & -0.024 & $-0.241^{*}$ & 0.106 & -2.270 & -0.451 & -0.032 \\
\hline Gender & 0.021 & 0.081 & 0.264 & -0.138 & 0.181 & 0.071 & 0.069 & 1.027 & -0.065 & 0.207 \\
\hline Edu & 0.115 & 0.078 & 1.479 & -0.038 & 0.268 & 0.016 & 0.067 & 0.236 & -0.115 & 0.146 \\
\hline Age1 & $0.257^{* *}$ & 0.101 & 2.533 & 0.058 & 0.456 & 0.052 & 0.087 & 0.591 & -0.120 & 0.223 \\
\hline Age2 & 0.211 & 0.112 & 1.883 & -0.009 & 0.430 & 0.020 & 0.096 & 0.204 & -0.169 & 0.208 \\
\hline Age3 & 0.187 & 0.184 & 1.018 & -0.174 & 0.548 & -0.196 & 0.157 & -1.243 & -0.505 & 0.114 \\
\hline Exp1 & -0.065 & 0.092 & -0.704 & -0.246 & 0.116 & $0.178^{*}$ & 0.079 & 2.264 & 0.023 & 0.333 \\
\hline Exp2 & -0.087 & 0.094 & -0.922 & -0.271 & 0.098 & 0.131 & 0.080 & 1.627 & -0.027 & 0.288 \\
\hline PFB & $0.537^{* * *}$ & 0.038 & 14.003 & 0.462 & 0.613 & $0.482^{* * *}$ & 0.041 & 11.655 & 0.401 & 0.564 \\
\hline PR & $-0.282^{* * *}$ & 0.038 & -7.384 & -0.357 & -0.207 & $-0.095^{*}$ & 0.035 & -2.714 & -0.163 & -0.026 \\
\hline SAT & & & & & & $0.287^{* * *}$ & 0.043 & 6.686 & 0.203 & 0.371 \\
\hline $\mathrm{PFB}^{*} \mathrm{PR}$ & $-0.181^{* * *}$ & 0.034 & -5.367 & -0.247 & -0.114 & $-0.125^{* *}$ & 0.041 & -3.080 & -0.206 & -0.045 \\
\hline SAT*PR & & & & & & -0.063 & 0.042 & -1.481 & -0.146 & 0.021 \\
\hline$R^{2}$ & 0.471 & & & & & 0.617 & & & & \\
\hline$F$ & $35.44^{* * *}$ & & & & & $53.157^{* * *}$ & & & & \\
\hline
\end{tabular}

Note:

- $\quad$ Control variables Age, Gender, Education and E-Tax Exparience are dummy coded

- ${ }^{*} p<0.05,{ }^{* *} p<0.01,{ }^{* * *} p<0.001$

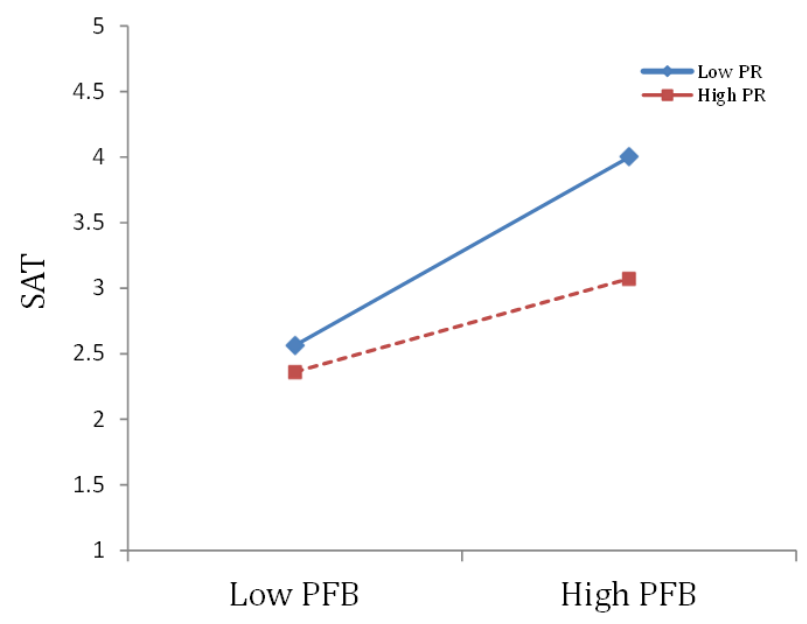

Figure 2: Moderating effect of PR on the relationship between PFB and SAT 


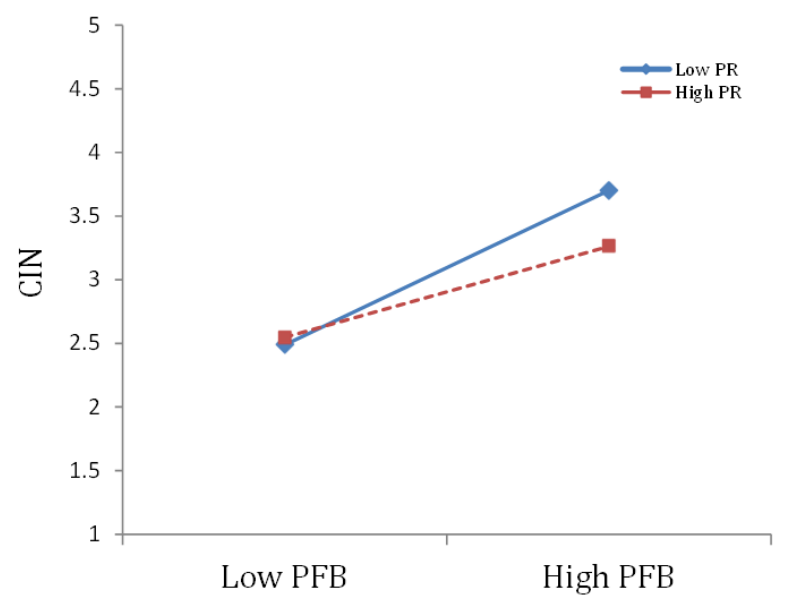

Figure 3: Moderating effect of PR on the relationship between PFB and CIN

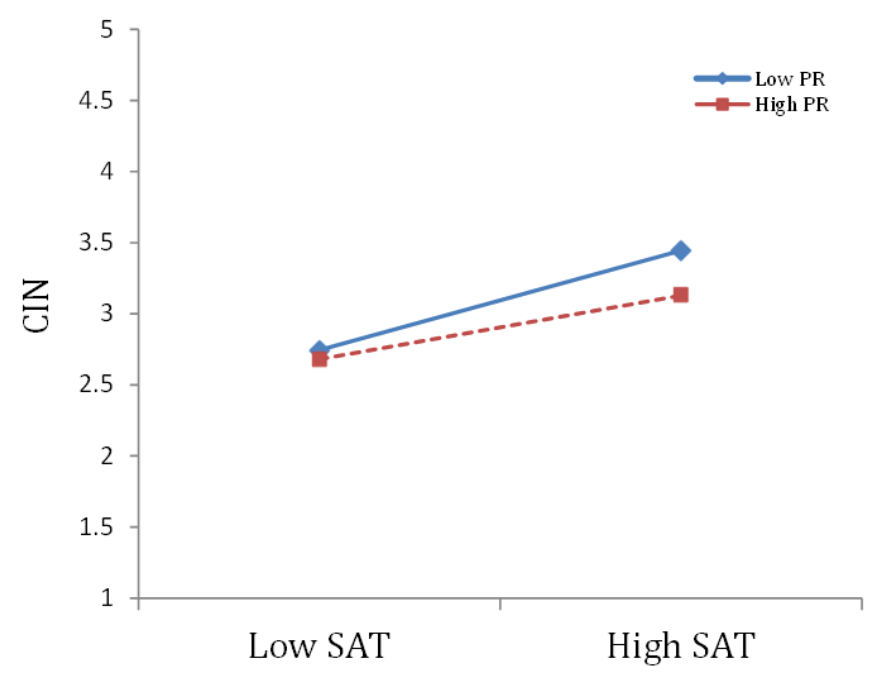

Figure 4: Moderating effect of PR on the relationship between PFB and SAT

\section{Discussion}

On the basis of the literature on IS success (Delone \& McLean, 2003) and IS continuance (Bhattacherjee, 2001), this research presents a comprehensive model of citizens' e-tax continuance in an emerging economy, such that these services are at the initial phase of their development. In this model, we propose that IS success drivers, such as quality of e-tax 
websites, influences citizens' continuance intention for e-tax filing directly and indirectly through confirmation of expectation, PFB, and satisfaction.

The results have been drawn with the help of covariance-based structural equation modeling which provides significant support for the proposed conceptual model. The overall variance explained $(\mathrm{R} 2=68 \%$ ) for the continuance intention shows the high explanatory power of the proposed model. H1 positing the positive effect of users' satisfaction on their e-tax filing continuance intention is accepted as $(\beta=0.275, \mathrm{p}<0.001)$. This finding substantiates the literature on users' satisfaction and continuance intention relation, in general (Bhattacherjee, 2001; Hsu \& Chiu, 2004) and in e-tax filing ,in particular (Teo et al., 2008; Veeramootoo et al., 2018). The confirmation of users' satisfaction and continuance intention relationship, in e-tax filing context, reaffirms the robustness of this association (Valaei \& Baroto, 2017; Venkatesh et al., 2011).

Results provide a strong support for $\mathrm{H} 2$ and $\mathrm{H} 3$ that suggest that PFB from e-tax filing is positively associated with satisfaction with e-tax filing $(\beta=0.464, \mathrm{p}<0.001)$ and continuance usage intention $(\beta=0.338, \mathrm{p}<0.001)$. These strong positive effects show that e-tax filing is useful and beneficial to taxpayers. Relative benefits that citizens perceive include convenience/accessibility while reducing waiting time and leading to quick response. Our results are consistent with the literature showing that citizens may adopt etax services perceiving that such services can provide them with relative advantages as compared with traditional governments (Carter \& Bélanger, 2005; Gilbert et al., 2004). Shareef et al. (2011), in their study conducted in Canada, also affirmed PFB as a significant driver of e-government adoption.

H4 proposes a positive relationship between citizens' confirmation of expectation from e-tax systems and their PFB, thereby accepting that the former significantly affects the latter $(\beta=$ $0.433, \mathrm{p}<0.001$ ). This benefit has been derived from perceived usefulness and relative advantage (Shareef et al., 2011), and ECM-ISC literature (Bhattacherjee, 2001; Venkatesh et al., 2011) confirms the perceived positive effect of confirmation of expectation on perceived usefulness. Therefore, this finding is in line with the literature on e-tax filing (Thominathan Santhanamery \& Ramayah, 2014). 
H5 postulates a relationship between confirmation of expectation and satisfaction with e-tax systems. Findings support this hypothesis as confirmation of expectation significantly affects satisfaction ( $\beta=0.290, \mathrm{p}<0.001)$. This result is consistent with the findings of ECM-ISC in various contexts (Bhattacherjee, 2001; Thominathan Santhanamery \& Ramayah, 2014; Veeramootoo et al., 2018; Venkatesh et al., 2011). H4 and H5 indicate the significance of confirmation of expectation in developing users' PFB and satisfaction, which are essential antecedents of e-tax filing continuance.

In H6, the perceived quality of e-tax website dimensions (i.e., information, system, and service) are suggested to positively influence (a) PFB and (b) confirmation of expectation. Information quality has significant positive effects on PFB $(\beta=0.188, \mathrm{p}<0.01)$ and confirmation of expectation $(\beta=0.267, \mathrm{p}<0.01)$. Moreover, service quality has significant positive effects on PFB $(\beta=0.187, \mathrm{p}<0.01)$ and confirmation of expectation $(\beta=0.246, \mathrm{p}$ $<0.01$ ). However, the effect of system quality is significant only on the confirmation of expectation $(\beta=0.246, \mathrm{p}<0.01)$, not on PFB $(\beta=0.088, \mathrm{p}=0.310)$. The study finds significant support for the proposed mediating role of confirmation of expectation, PFB, and satisfaction on the relationship between e-tax websites' perceived quality dimensions and continuance intention. The direct effects of information $(\beta=0.054, \mathrm{p}=0.348)$, system $(\beta=$ $0.081, p=0.206)$, and service $(\beta=0.068, p=0.321)$ quality on continuance intention are insignificant. Results related to these direct effects of information, system, and service quality on continuance intention should be interpreted with caution as these insignificant values are due to mediating variables. In the absence of these mediating variables, the relationship between quality constructs and e-tax filing continuance are significant. Nevertheless, the total indirect effects of information $(\beta=0.193, \mathrm{p}<0.01)$, system $(\beta=$ $0.129, \mathrm{p}<0.01)$, and service $(\beta=0.186, \mathrm{p}<0.01)$ quality on continuance intention are significant. Direct effects of e-tax websites' quality dimension on continuance intention are insignificant; whereas, indirect effects are significant. Thus, the relationship between the dimensions of e-tax websites and continuance intention are fully mediated by intervening variables. Consequently, H7 is supported. These empirical results confirm that, while egovernment website characteristics, such as information, system, and service quality play an important role in forming citizens' future usage intention, understanding the role of key 
intervening variables, such as confirmation of expectation, functional benefit, and satisfaction is necessary. These results are broadly consistent with the literature on IS success (Lee \& Chung, 2009; Stefanovic et al., 2016; Teo et al., 2008; Veeramootoo et al., 2018).

Perceived risk has a significant moderating effect on the relationship between PFB and satisfaction $[\beta=-0.181, \mathrm{p}<0.001]$. The negative estimate indicates that the relationship between PFB and satisfaction strengthens with the decrease in the extent of perceived risk. Consequently, compared with high perceived risk, low perceived risk strengthens the relationship between PFB and satisfaction, thereby supporting H8a. Moreover, the interaction effect of perceived risk on the relationship between PFB and continuance intention is also significant $\left[\beta=-0.125^{* *}, \mathrm{p}<0.01\right]$. Therefore, compared with high perceived risk, low perceived risk strengthens the relationship between PFB and continuance intention, lending support to H8b. Finally, the interaction effect of perceived risk on the relationship between satisfaction on continuance intention is not significant $[\beta=$ $-0.063, p<0.10]$. Though perceived risk doesn't have a significant effect on the relationship between satisfaction and continuance intention; nonetheless, the role of perceived risk is relevant in determining citizens' future usage intention for e-tax services. Extant literature has considered perceived risk as an antecedent of intention to e-tax filing (Hsu \& Chiu, 2004; Hung et al., 2006; Schaupp et al., 2010; Veeramootoo et al., 2018). No empirical evidence is available regarding the role of perceived risk on relationships among functional benefit, satisfaction, and continuance intention. This study contributes to the literature on e-tax filing continuance by providing an empirical evidence for the role of perceived risk as a moderating variable on relationships among functional benefit, satisfaction, and continuance intention.

The results show statistically insignificant association between any of the control variables and continuance intention except for the e-tax experience between 2 to 3 years. The insignificant effects of gender and age contradict with the previous literature (Santhanamery \& Ramayah, 2015) that suggests the significant effects of these variables on e-tax filing continuance. However, these results are consistent with Stefanovic et al. (2016) who did not find any significant effect of age and gender on intention to use e-government services. 


\section{Theoretical Implications}

From theoretical perspective, this research makes significant contributions by enhancing our current understanding of IS continuous intention to e-tax filing. Online tax filing is mostly assessed from acceptance and adoption perspective. However, adoption and continuance intention, as distinct behavioral concepts, cannot be measured using the same theoretical foundation (Bhattacherjee, 2001). Therefore, instead of employing classical theories of technology adoption, such as TAM, TPB, and UTAUT, this study builds on technical and behavioral aspects of e-tax filing continuance to make a compelling theoretical argument and proposes a comprehensive framework. To incorporate the technical and behavioral aspects of continuance intention, this study builds on ECM-ISC and IS success model. In addition, the study contributes to the literature on IS continuance by adding PFB as a mediating, perceived risk as a moderating, and users' demographics as control variables.

E-tax filing research has focused on the trusting anatomy for e-tax filing system. The authors do believe that trust has the fundamental impact on e-government service adoption and continuance. However, the dynamics of trust are broader, ambiguous and time-consuming. Based on the verdicts of past studies, the authors have opted for an alternative and more user-centric constructs, such as PFB, confirmation, satisfaction and risk to better portray the acceptance of e-tax filing system.

The literature on e-tax filing has generally considered quality variables as the direct predictors of continuance behavior (Nabavi et al., 2016; Veeramootoo et al., 2018). This research extends, such a finding, by exploring the direct and indirect effects of quality constructs. In the literature on e-tax filing, perceived risk has been studied as a barrier to its adoption (Schaupp et al., 2010). This study makes another notable contribution by assessing the effects of high or low perceived risk conditions on relationships among functional benefit, satisfaction, and continuance intention. Results reveal that low-risk condition results in strengthened relationships between PFB and satisfaction as well as between PFB and continuance intention.

The three quality constructs from the IS success model enhance the confirmation among taxpayers, allowing them to extract the desired functional benefit and satisfaction. The empirical results, laid in this study, prove that the relationships among system quality, 
confirmation, PFB, and satisfaction strengthen our intuition of using ECM-ISC in connection with the IS success model as the theoretical basis for measuring continuous intention for etax filing services. The explained variance $\left(R^{2}=68 \%\right)$ of continuous intention suggests that ECM-ISC and IS success models may be used together in the future to extract convincing results for measuring e-government continuance usage.

\section{Practical Implications}

Governments' responsibility does not end with only providing infrastructures. They must understand the diverse needs of taxpayers, who may be having technological or psychological issues in the use of such services. Governments spend much financial and human resources to setup e-tax services. However, these investments do not guarantee the success of such services because of the heterogeneous nature of e-tax users and their various preferences. The benefits extracted from such the e-tax filing system are not unidirectional as governments are also the beneficiaries of these systems due to their efficient revenue collection (Veeramootoo et al., 2018).

The results of this study will be beneficial to the policymakers as, based on these findings, they can develop strategies to better improve e-filing services which will result in enhanced citizens continues usage intention. Results suggest that to understand citizen's continuance intention for e-services, e-government policymakers must focus not only on technical characteristics, such as website quality but also on citizens' psychological characteristics, such as their confirmation of expectation, satisfaction, PFB, and perceived risk.

Results affirm that website quality plays a significant role in users' decision about continuous usage. Thus, policymakers must focus on this aspect of e-tax filing websites (Floropoulos et al., 2010). Specifically, they must improve the quality of the systems, information, and services that they offer through such channels. In addition, high-quality e-tax websites in terms of information, content, feedback, security, and privacy may result in conformity of users' expectation; thereby, increasing their PFB and satisfaction, which subsequently results in continuance intention.

Generally, user's decisions are influenced by perceived benefits and the results indicate that PFB is a major predictor of continuance for e-tax filing. So, policymakers need to effectively communicate the functional benefits of using e-tax filing system. Policymakers should 
strategize the formulation of e-tax filing system to elucidate its benefits to users. Abolishing technical glitches and complexities allows e-governments to create motivation among taxpayers in extracting functional benefits, which are significant drivers of continuous intention for the e-tax filers. As PFB is linked to the understanding of facilitation to the etaxpayers, the policymakers should devise e-tax filing systems which are quick and responsive. To augment the efficiency of e-tax filing system and its continuous usage, government can facilitate taxpayers by providing user's manuals, online help desks and 24 hours assistance.

Moreover, we must not forget perceived risk, which stays as a never-ending feeling in the behavioral intent of users unless addressed appropriately (Schaupp \& Carter, 2010). Highrisk perceptions weaken relationships among PFB, satisfaction, and continuance intention but users' decisions are generally based on the perceived gains rather than losses (Kahneman \& Tversky, 1979). Therefore, governments must highlight the potential benefits of online channels to mitigate risk perceptions. In addition, policymakers must take initiatives to reduce users' concerns by updating e-tax filing systems' security and assuring users the privacy and security of their personal information. Moreover, policymakers may offer incentives to online tax filers, such as tax rebates upon changes in tax policies.

In areas where internet facilities are not adequate, government may develop regional centers where taxpayers may access e-filing systems. Government may also install internet enabled kiosks to access various e-tax services at public places. As e-tax paying systems are multifaceted, personal on-site assistance should be provided by the tax collection departments to assist smooth transactions. Furthermore, educating users through seminars and webinars on the usage of e-tax systems should be often exercised. Through training and online tutorials, the policymakers can intensify the e-tax filing usage among taxpayers. Not only the use of such system will be extended but also the knowledge and skills of taxpayers will be enhanced. Moreover, appropriate marketing of online channel would attract taxpayers for using e-tax filing system.

Lastly, user-friendly and technology-enabled e-tax filing services can create an environment to match users' expectations, wherein they can benefit from government e-tax services. The level of service to taxpayers can be improved by providing up-to-date information, on web 
portals, about tax services, documentation, and new government policies. The facility of eservices through government web-portals is an innovative process that needs continuous improvement. The smart use of ICTs may permit governments to maximize their capabilities and offer quality services to the taxpayers.

\section{Conclusion}

E-tax filing is a potential research area in academics as it has a direct impact on countries' economy, which subsequently affects various institutions directly linked with the public. The study contributes to the literature on e-tax filing by providing a theoretical underpinning and an empirical evidence for e-tax filing continuance intention in an emerging economy context. Most research on e-tax filing has focused on initial adoption, and this study extends the previous research by providing a compelling understanding of continuous usage behavior. The study provides an extended framework of e-tax filing continuance by incorporating behavioral constructs from ECM-ISC and technological constructs from the IS success model combined with PFB and perceived risk. The empirical results confirm the combination of ESC-ISC, and D\&M IS success model provides an adequate foundation for studying IS success and continuance such as e-tax filing.

\section{Limitations and Future Research}

The research discusses an important issue of e-tax filing continuance intention in the context of an emerging economy, but certain limitations exist. These limitations should be considered before making conclusions based on the findings. First, this study does not assess users' actual e-tax filing behavior but has developed a theoretical framework for measuring e-tax filing continuance intention. Users' actual e-tax filing behavior may not necessarily result from continuance behavior (Dwivedi et al., 2017; Veeramootoo et al., 2018). Second, this research has included quality constructs from the IS success model and behavioral constructs from ECM-ISC, but other important variables such as, habit, trust, self-efficacy, and social influence may influence continuance intention. Future research can incorporate such constructs to further extend this model and offer robust findings. Third, although exante and ex-post efforts are made to avoid CMV yet self-reported measures in a crosssectional design may be subject to CMV and may result in inflated relationships. Fourth, the 
rapid environmental changes with respect to technology may have a favorable impact on users' attitude toward e-tax filing. Thus, a longitudinal study may provide good insights into variations in consumers' attitude over the period. Fifth, e-tax filing behavior may vary across different platforms, such as personal computers and portable devices as well as mobile applications. Future research may test the proposed model across different platforms and compare its validity through mobile applications versus websites. Sixth, the surveys have been carried out in English language because most government websites, in the field of study, are offered in English; moreover, the purpose was to retain the essence of the original scales. However, this may have caused comprehension problems to certain respondents. Finally, future research can also explore the role of social media, such as social networks, blogs, discussion forums, and wikis on users' continuance intention of e-tax filing. This impact may vary among various age groups and help policymakers design e-tax services catering to the needs of users from different age groups.

\section{Appendix-A: Latent constructs' measures}

Information Quality adapted from Stefanovic et al., (2016) and Wang \& Liao (2008)

- E-tax filing system provides accurate information.

- E-tax filing system provides clear information.

0.847

- E-tax filing system provides relevant information.

0.754

- E-tax filing system provides up-to-date information.

0.743

System Quality adapted from Stefanovic et al., (2016) and Wang \& Liao (2008)

- It is convenient (easy to use) to access e-tax filing system.

0.800

- E-tax filing system is reliable.

0.756

- E-tax filing system is flexible (user-friendly).

0.790

- E-tax filing system allows information to be readily accessible to me.

0.715

Service Quality adapted from Stefanovic et al., (2016) and Wang \& Liao (2008)

- E-tax filing system is always ready to help.

0.733

- E-tax filing system is available at all times.

0.750

- E-tax system gives you individual attention.

0.748

- Transactions within the e-tax filing system are secure and protect privacy.

0.698

Confirmation adapted from Bhattacherjee (2001)

- My experience with using e-tax filing system was better than what I expected. 0.777

- The service level provided by e-tax filing was better than what I expected.

0.799

- Overall, most of my expectations from using e-tax filing were confirmed.

0.736

Functional Benefit adapted from Carter \& Bélanger (2005) and Shareef et al., (2011)

- Using e-tax filing website enhances overall efficiency.

0.738 
- Using e-tax filing website makes it easier to perform tasks.

- Using e-tax filing website improves the quality of decision-making.

- It does not take too much time to seek service from the e-tax filing website, as compared to traditional government service.

Satisfaction adapted from Bhattacherjee (2001)

How do you feel about your overall experience of using the e-tax filing?

- Very dissatisfied... Very satisfied

- Very displeased... Very pleased

0.792

- Very frustrated ... Very contented

0.756

- Absolutely terrible ... Absolutely delighted

0.756

Perceived Risk adapted from Carter \& Bélanger (2005) and Schaupp et al., (2010)

- I will feel uneasy psychologically if I use the internet to file my tax filing.

- Use of e-tax filing system may cause my personal information to be stolen.

- I think it would be unsafe to use e-tax filing methods because of the privacy and security concerns.

- I believe that there could be negative consequences by using an e-tax filing system.

Continuance Intention adapted from Bhattacherjee (2001)

- I intend to continue using the e-tax filing in future.

0.856

- I intend to continue using e-tax filing rather than using any alternative means.

0.834

- I will continue using the e-tax filing in future.

0.817

- I will continue using the e-tax filing for my income tax returns. 


\section{Appendix-B: Specific indirect effects}

\begin{tabular}{|c|c|c|c|c|c|}
\hline \multirow{2}{*}{ Path } & \multirow{2}{*}{ Estimate } & \multirow{2}{*}{ SE } & \multicolumn{2}{|c|}{ Bootstrap Confidence intervals } & \multirow{2}{*}{ P-values } \\
\hline & & & Lower & Upper & \\
\hline $\mathrm{INQ} \rightarrow \mathrm{CNF} \rightarrow \mathrm{PFB}$ & 0.134 & 0.050 & 0.064 & 0.227 & 0.001 \\
\hline $\mathrm{INQ} \rightarrow \mathrm{CNF} \rightarrow \mathrm{PFB} \rightarrow \mathrm{SAT}$ & 0.051 & 0.023 & 0.023 & 0.100 & 0.001 \\
\hline $\mathrm{INQ} \rightarrow \mathrm{CNF} \rightarrow \mathrm{PFB} \rightarrow \mathrm{SAT} \rightarrow \mathrm{CIN}$ & 0.016 & 0.009 & 0.007 & 0.040 & 0.000 \\
\hline $\mathrm{INQ} \rightarrow \mathrm{CNF} \rightarrow \mathrm{PFB} \rightarrow \mathrm{CIN}$ & 0.056 & 0.023 & 0.026 & 0.104 & 0.001 \\
\hline $\mathrm{INQ} \rightarrow \mathrm{CNF} \rightarrow \mathrm{SAT}$ & 0.074 & 0.030 & 0.034 & 0.136 & 0.000 \\
\hline $\mathrm{INQ} \rightarrow \mathrm{CNF} \rightarrow \mathrm{SAT} \rightarrow \mathrm{CIN}$ & 0.024 & 0.012 & 0.011 & 0.054 & 0.000 \\
\hline $\mathrm{INQ} \rightarrow \mathrm{PFB} \rightarrow \mathrm{SAT}$ & 0.084 & 0.035 & 0.034 & 0.144 & 0.012 \\
\hline $\mathrm{INQ} \rightarrow \mathrm{PFB} \rightarrow \mathrm{SAT} \rightarrow \mathrm{CIN}$ & 0.027 & 0.013 & 0.010 & 0.054 & 0.007 \\
\hline INQ $\rightarrow$ PFB $\rightarrow$ CIN & 0.091 & 0.042 & 0.030 & 0.167 & 0.017 \\
\hline $\mathrm{SYQ} \rightarrow \mathrm{CNF} \rightarrow \mathrm{PFB}$ & 0.124 & 0.050 & 0.053 & 0.214 & 0.004 \\
\hline $\mathrm{SYQ} \rightarrow \mathrm{CNF} \rightarrow \mathrm{PFB} \rightarrow \mathrm{SAT}$ & 0.048 & 0.020 & 0.021 & 0.087 & 0.002 \\
\hline $\mathrm{SYQ} \rightarrow \mathrm{CNF} \rightarrow \mathrm{PFB} \rightarrow \mathrm{SAT} \rightarrow \mathrm{CIN}$ & 0.015 & 0.007 & 0.007 & 0.033 & 0.001 \\
\hline $\mathrm{SYQ} \rightarrow \mathrm{CNF} \rightarrow \mathrm{PFB} \rightarrow \mathrm{CIN}$ & 0.052 & 0.023 & 0.023 & 0.099 & 0.003 \\
\hline $\mathrm{SYQ} \rightarrow \mathrm{CNF} \rightarrow \mathrm{SAT}$ & 0.069 & 0.036 & 0.022 & 0.139 & 0.003 \\
\hline $\mathrm{SYQ} \rightarrow \mathrm{CNF} \rightarrow \mathrm{SAT} \rightarrow \mathrm{CIN}$ & 0.022 & 0.012 & 0.007 & 0.050 & 0.002 \\
\hline $\mathrm{SYQ} \rightarrow \mathrm{PFB} \rightarrow \mathrm{SAT}$ & 0.039 & 0.041 & -0.016 & 0.121 & 0.255 \\
\hline $\mathrm{SYQ} \rightarrow \mathrm{PFB} \rightarrow \mathrm{SAT} \rightarrow \mathrm{CIN}$ & 0.012 & 0.014 & -0.005 & 0.041 & 0.242 \\
\hline $\mathrm{SYQ} \rightarrow \mathrm{PFB} \rightarrow \mathrm{CIN}$ & 0.043 & 0.043 & -0.019 & 0.125 & 0.252 \\
\hline $\mathrm{SEQ} \rightarrow \mathrm{CNF} \rightarrow \mathrm{PFB}$ & 0.128 & 0.052 & 0.058 & 0.230 & 0.002 \\
\hline $\mathrm{SEQ} \rightarrow \mathrm{CNF} \rightarrow \mathrm{PFB} \rightarrow \mathrm{SAT}$ & 0.049 & 0.022 & 0.022 & 0.096 & 0.001 \\
\hline $\mathrm{SEQ} \rightarrow \mathrm{CNF} \rightarrow \mathrm{PFB} \rightarrow \mathrm{SAT} \rightarrow \mathrm{CIN}$ & 0.016 & 0.008 & 0.007 & 0.036 & 0.001 \\
\hline $\mathrm{SEQ} \rightarrow \mathrm{CNF} \rightarrow \mathrm{PFB} \rightarrow \mathrm{CIN}$ & 0.054 & 0.024 & 0.025 & 0.107 & 0.002 \\
\hline $\mathrm{SEQ} \rightarrow \mathrm{CNF} \rightarrow \mathrm{SAT}$ & 0.071 & 0.033 & 0.031 & 0.143 & 0.002 \\
\hline $\mathrm{SEQ} \rightarrow \mathrm{CNF} \rightarrow \mathrm{SAT} \rightarrow \mathrm{CIN}$ & 0.023 & 0.012 & 0.010 & 0.054 & 0.001 \\
\hline $\mathrm{SEQ} \rightarrow \mathrm{PFB} \rightarrow \mathrm{SAT}$ & 0.087 & 0.043 & 0.024 & 0.165 & 0.015 \\
\hline $\mathrm{SEQ} \rightarrow \mathrm{PFB} \rightarrow \mathrm{SAT} \rightarrow \mathrm{CIN}$ & 0.027 & 0.015 & 0.009 & 0.061 & 0.008 \\
\hline $\mathrm{SEQ} \rightarrow \mathrm{PFB} \rightarrow \mathrm{CIN}$ & 0.094 & 0.048 & 0.027 & 0.181 & 0.015 \\
\hline
\end{tabular}

Note:

- $\quad I N Q=$ Information Quality, $S Y Q=$ System Quality, $S E Q=$ Service Quality, $C N F=$ Confirmation of Expectation, $P F B=$ Perceived Functional Benefit, $P R=P e r c e i v e d$ Risk, SAT= Satisfaction, CIN= Continuance Intention, $P$-values are two-tailed significance,,$S E=$ Standard error

\section{Acknowledgments}

The researchers would like to thank the Deanship of Scientific Research at King Saud University represented by the Research Centre at College of Business Administration for supporting this research financially. 


\section{References}

Anderson, J. C., \& Gerbing, D. W. (1988). Structural equation modeling in practice: A review and recommended two-step approach. Psychological Bulletin, 103(3), 411-423. https://doi.org/10.1037/0033-2909.103.3.411

Bélanger, F., \& Carter, L. (2008). Trust and risk in e-government adoption. The Journal of $\begin{array}{llll}\text { Strategic Information } & \text { Systems, } & 17(2), & 165-176 .\end{array}$ https://doi.org/10.1016/j.jsis.2007.12.002

Bhattacherjee, A. (2001). Understanding Information Systems Continuance: An ExpectationConfirmation Model. MIS Quarterly, 25(3), 351-370. https://doi.org/10.2307/3250921

Bhuasiri, W., Zo, H., Lee, H., \& Ciganek, A. P. (2016). User Acceptance of e-government Services: Examining an e-tax Filing and Payment System in Thailand. Information $\begin{array}{llll}\text { Technology for } & \text { 22(4), 6evelopment, }\end{array}$ https://doi.org/10.1080/02681102.2016.1173001

Byrne, B. M. (2016). Structural equation modeling with Amos : basic concepts, applications, and programming (3rd ed.). Routledge.

Carter, L., \& Bélanger, F. (2005). The utilization of e-government services: citizen trust, innovation and acceptance factors. Information Systems Journal, 15(1), 5-25. Retrieved from http://dx.doi.org/10.1111/j.1365-2575.2005.00183.x

Carter, L., Shaupp, L. C., Hobbs, J., \& Campbell, R. (2011). The role of security and trust in the adoption of online tax filing. Transforming Government: People, Process and Policy, 5(4), 303-318. https://doi.org/10.1108/17506161111173568

Carter, L., Weerakkody, V., Phillips, B., \& Dwivedi, Y. K. (2016). Citizen Adoption of EGovernment Services: Exploring Citizen Perceptions of Online Services in the United States and United Kingdom. Information Systems Management, 33(2), 124-140. https://doi.org/10.1080/10580530.2016.1155948

Chang, I. C., Li, Y. C., Hung, W. F., \& Hwang, H. G. (2005). An empirical study on the impact of quality antecedents on tax payers' acceptance of Internet tax-filing systems. Government Information Quarterly, 22(3), 389-410. https://doi.org/10.1016/j.giq.2005.05.002

Chaouali, W., Yahia, I. Ben, Charfeddine, L., \& Triki, A. (2016). Understanding citizens' adoption of e-filing in developing countries: An empirical investigation. Journal of High 
Technology Management Research, 27(2), 161-176. https://doi.org/10.1016/j.hitech.2016.10.006

Chen, C.-W. (2010). Impact of quality antecedents on taxpayer satisfaction with online taxfiling systems-An empirical study. Information \& Management, 47(5-6), 308-315. https://doi.org/10.1016/J.IM.2010.06.005

Chen, J. V., Jubilado, R. J. M., Capistrano, E. P. S., \& Yen, D. C. (2015). Factors affecting online tax filing - An application of the IS Success Model and trust theory. Computers in Human Behavior, 43, 251-262. https://doi.org/10.1016/j.chb.2014.11.017

Chou, S.-W., Min, H.-T., Chang, Y.-C., \& Lin, C.-T. (2010). Understanding continuance intention of knowledge creation using extended expectation-confirmation theory: an empirical study of Taiwan and China online communities. Behaviour \& Information Technology, 29(6), 557-570. https://doi.org/10.1080/01449290903401986

Davis, F. D. (1989). Perceived Usefulness, Perceived Ease of Use, and User Acceptance of Information Technology. MIS Quarterly, 13(3), 319-340. https://doi.org/10.2307/249008

Delone, W. H., \& McLean, E. R. (2003). The DeLone and McLean Model of Information Systems Success: A Ten-Year Update. Journal of Management Information Systems, 19(4), 9-30. Retrieved from http://portal.acm.org/citation.cfm?id=1289767

DeLone, W. H., \& McLean, E. R. (1992). Information Systems Success: The Quest for the Dependent Variable. Information Systems Research, 3(1), 60-95. https://doi.org/10.1287/isre.3.1.60

DeLone, W. H., \& McLean, E. R. (2016). Information Systems Success Measurement. Foundations and Trends ${ }^{\circledR}$ in Information Systems, 2(1), 1-116. https://doi.org/10.1561/2900000005

Dorasamy, M., Marimuthu, M., Raman, M., \& Kaliannan, M. (2010). e-government services online: An exploratory study on tax e-Filing in Malaysia. International Journal of Electronic Government $\quad$ Research, 6(4), 12-24. https://doi.org/10.4018/jegr.2010100102

Dwivedi, Y. K., Rana, N. P., Janssen, M., Lal, B., Williams, M. D., \& Clement, M. (2017). An empirical validation of a unified model of electronic government adoption (UMEGA). 
Government Information Quarterly, 34(2), 211-230. https://doi.org/10.1016/j.giq.2017.03.001

Dwivedi, Y. K., Shareef, M. A., Simintiras, A. C., Lal, B., \& Weerakkody, V. (2016). A generalised adoption model for services: A cross-country comparison of mobile health (m-health).

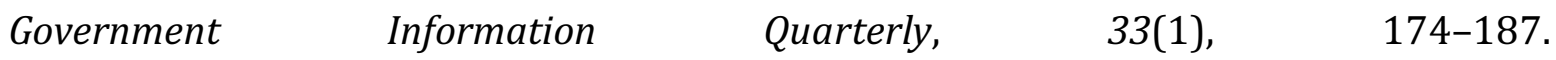
https://doi.org/10.1016/j.giq.2015.06.003

Fakhoury, R., \& Aubert, B. (2015). Citizenship, trust, and behavioural intentions to use public e-services: The case of Lebanon. International Journal of Information Management, 35(3), 346-351. https://doi.org/10.1016/j.ijinfomgt.2015.02.002

FBR. (2018). Active Taxpayer List, Pakistan. Retrieved from http://www.fbr.gov.pk/

Floropoulos, J., Spathis, C., Halvatzis, D., \& Tsipouridou, M. (2010). Measuring the success of the Greek Taxation Information System. International Journal of Information Management, 30(1), 47-56. https://doi.org/10.1016/j.ijinfomgt.2009.03.013

Fornell, C., \& Larcker, D. (1981). Evaluating Structural Equation Models with Unobservable Variables and Measurement Error. Journal of Marketing Research, 18(1), 50, 39.

Fu, J.-R., Farn, C.-K., \& Chao, W.-P. (2006). Acceptance of electronic tax filing: A study of taxpayer intentions. Information \& Management, 43(1), 109-126. https://doi.org/10.1016/J.IM.2005.04.001

Gauld, R., Goldfinch, S., \& Horsburgh, S. (2010). Do they want it? Do they use it? The `DemandSide' of e-Government in Australia and New Zealand. Government Information Quarterly, 27(2), 177-186. https://doi.org/10.1016/j.giq.2009.12.002

Gilbert, D., Balestrini, P., \& Littleboy, D. (2004). Barriers and benefits in the adoption of egovernment. International Journal of Public Sector Management, 17(4), 286-301. https://doi.org/10.1108/09513550410539794

Guide, V. D. R., \& Ketokivi, M. (2015). Notes from the Editors: Redefining some methodological criteria for the journal. Journal of Operations Management, 37, v-viii. https://doi.org/10.1016/S0272-6963(15)00056-X

Gupta, B., Dasgupta, S., \& Gupta, A. (2008). Adoption of ICT in a government organization in a developing country: An empirical study. The Journal of Strategic Information Systems, 17(2), 140-154. https://doi.org/10.1016/j.jsis.2007.12.004 
Hair, J. F., Wolfinbarger, M., Money, A. H., Samouel, P., \& Page, M. J. (2011). Essentials of business research methods (2nd ed.). Routledge.

Hayes, A. F. (2013). Introduction to mediation, moderation, and conditional process analysis: A regression-based approach. New York: The Guilford Press.

Henseler, J., Ringle, C. M., \& Sarstedt, M. (2015). A new criterion for assessing discriminant validity in variance-based structural equation modeling. Journal of the Academy of Marketing Science, 43(1), 115-135. https://doi.org/10.1007/s11747-014-0403-8

Hong, J.-C., Tai, K.-H., Hwang, M.-Y., Kuo, Y.-C., \& Chen, J.-S. (2017). Internet cognitive failure relevant to users' satisfaction with content and interface design to reflect continuance intention to use a government e-learning system. Computers in Human Behavior, 66, 353-362. https://doi.org/10.1016/j.chb.2016.08.044

Hsu, M.-H., \& Chiu, C.-M. (2004). Predicting electronic service continuance with a decomposed theory of plananed behaviour. Behaviour \& Information Technology, 23(5), 359-373. https://doi.org/10.1080/01449290410001669969

Hu, L., \& Bentler, P. M. (1999). Cutoff criteria for fit indexes in covariance structure analysis: conventional criteria versus New alternatives. Structural Equation Modeling, 6(1), 1-55.

Hu, P. J.-H., Brown, S. A., Thong, J. Y. L., Chan, F. K. Y., \& Tam, K. Y. (2009). Determinants of Service Quality and Continuance Intention of Online Services:The Case of eTax. Journal of The American Society For Information Science And Technology, 60(2), 292-306. https://doi.org/10.1002/asi

Hung, S. Y., Chang, C. M., \& Yu, T. J. (2006). Determinants of user acceptance of the eGovernment services: The case of online tax filing and payment system. Government Information Quarterly, 23(1), 97-122. https://doi.org/10.1016/j.giq.2005.11.005

Hussein, R., Mohamed, N., Ahlan, R., \& Mahmud, M. (2011). E-government application: an integrated model on G2C adoption of online tax. Transforming Government: People, Process and Policy, 5(3), 251-282. Retrieved from 10.1108/17506161111155388

Kahneman, D., \& Tversky, A. (1979). Prospect Theory: An Analysis of Decision under Risk. Econometrica, 47(2), 263-291. https://doi.org/10.2307/1914185

Kline, R. B. (2010). Principles and Practice of Structural Equation Modeling (Third Edit). The Guilford Press. 
Kurfal, M., Ali, A., Tokdemir, G., \& Paçin, Y. (2017). Adoption of e-government services in Turkey. Computers in Human Behavior, 66, 168-178. https://doi.org/10.1016/j.chb.2016.09.041

Lallmahomed, M. Z. I., Lallmahomed, N., \& Lallmahomed, G. M. (2017). Factors influencing the adoption of e-Government Services in Mauritius. Telematics and Informatics, 34(4), 57-72. https://doi.org/10.1016/j.tele.2017.01.003

Lee, K. C., \& Chung, N. (2009). Understanding factors affecting trust in and satisfaction with mobile banking in Korea: A modified DeLone and McLean's model perspective. Interacting with $\quad$ Computers, 385-392. https://doi.org/10.1016/j.intcom.2009.06.004

Liang, S., \& Lu, H. (2013). Adoption of e-government services: an empirical study of the online tax filing system in Taiwan. Online Information Review, 37(3), 424-442. https://doi.org/10.1108/0IR-01-2012-0004

Lin, F., Fofanah, S. S., \& Liang, D. (2011). Assessing citizen adoption of e-Government initiatives in Gambia: A validation of the technology acceptance model in information systems success. Government Information Quarterly, 28(2), 271-279. https://doi.org/10.1016/j.giq.2010.09.004

Lin, X., Featherman, M., \& Sarker, S. (2017). Understanding factors affecting users' social networking site continuance: A gender difference perspective. Information \& Management, 54(3), 383-395. https://doi.org/10.1016/j.im.2016.09.004

Moore, G. C., \& Benbasat, I. (1991). Development of an Instrument to Measure the Perceptions of Adopting an Information Technology Innovation. Information Systems Research, 2(3), 192-222. https://doi.org/<p>10.1287/isre.2.3.192</p >

Nabavi, A., Taghavi-Fard, M. T., Hanafizadeh, P., \& Taghva, M. R. (2016). Information Technology Continuance Intention. International Journal of E-Business Research, 12(1), 58-95. https://doi.org/10.4018/IJEBR.2016010104

Nunnally, J. C. (1978). Psychometric Theory (2nd ed.). New York: Mcgraw-Hill College.

Ojha, A., Sahu, G. P., \& Gupta, M. P. (2009). Antecedents of paperless income tax filing by young professionals in India: an exploratory study. Transforming Government: People, Process and Policy, 3(1), 65-90. https://doi.org/10.1108/17506160910940740 
Pavlou, P. A. (2003). Consumer Acceptance of Electronic Commerce: Integrating Trust and Risk with the Technology Acceptance Model. International Journal of Electronic Commerce, 7(3), 101-134. $\quad$ Retrieved from http://portal.acm.org/citation.cfm?id=1288221

Podsakoff, P. M., MacKenzie, S. B., Lee, J.-Y., \& Podsakoff, N. P. (2003). Common method biases in behavioral research: a critical review of the literature and recommended remedies. The Journal of Applied Psychology, 88(5), 879-903. https://doi.org/10.1037/00219010.88.5.879

Porumbescu, G. A. (2016). Linking public sector social media and e-government website use to trust in government. Government Information Quarterly, 33(2), 291-304. https://doi.org/10.1016/j.giq.2016.04.006

Rai, A., Lang, S. S., \& Welker, R. B. (2002). Assessing the Validity of IS Success Models: An Empirical Test and Theoretical Analysis. Information Systems Research, 13(1), 50-69. https://doi.org/10.1287/isre.13.1.50.96

Rana, N. P., \& Dwivedi, Y. K. (2015). Citizen's adoption of an e-government system: Validating extended social cognitive theory (SCT). Government Information Quarterly, 32(2), 172181. https://doi.org/10.1016/j.giq.2015.02.002

Rana, N. P., Dwivedi, Y. K., \& Williams, M. D. (2015). A meta-analysis of existing research on citizen adoption of e-government. Information Systems Frontiers, 17(3), 547-563. https://doi.org/10.1007/s10796-013-9431-z

Rana, N. P., Dwivedi, Y. K., Williams, M. D., \& Weerakkody, V. (2015). Investigating success of an e-government initiative: Validation of an integrated IS success model. Information Systems Frontiers, 17(1), 127-142. https://doi.org/10.1007/s10796-014-9504-7

Rose, J., Persson, J. S., Heeager, L. T., \& Irani, Z. (2015). Managing e-Government: value positions and relationships. Information Systems Journal, 25(5), 531-571. https://doi.org/10.1111/isj.12052

Sá, F., Rocha, Á., \& Pérez Cota, M. (2016). From the quality of traditional services to the quality of local e-Government online services: A literature review. Government Information Quarterly, 33(1), 149-160. https://doi.org/10.1016/j.giq.2015.07.004

Sambasivan, M., Wemyss, G. P., \& Rose, R. C. (2010). User acceptance of a G2B system: a case 
of electronic procurement system in Malaysia. Internet Research, 20(2), 169-187. https://doi.org/10.1108/10662241011032236

Santhanamery, T., \& Ramayah, T. (2014). Explaining the e-Government Usage Using Expectation Confirmation Model: The Case of Electronic Tax Filing in Malaysia. In Government e-Strategic Planning and Management, Public Administration and Information Technology (pp. 287-304). https://doi.org/10.1007/978-1-4614-8462-2

Santhanamery, T., \& Ramayah, T. (2015). Understanding the Effect of Demographic and Personality Traits on the E-Filing Continuance Usage Intention in Malaysia. Global Business Review, 16(1), 1-20. https://doi.org/10.7763/JOEBM.2013.V1.6

Schaupp, L. C., \& Carter, L. (2010). The impact of trust, risk and optimism bias on e-file adoption. Information Systems Frontiers, 12(3), 299-309. https://doi.org/10.1007/s10796-008-9138-8

Schaupp, L. C., Carter, L., \& McBride, M. E. (2010). E-file adoption: A study of U.S. taxpayers' intentions. Computers in Human Behavior, 26(4), 636-644. https://doi.org/10.1016/j.chb.2009.12.017

Shan, S., Wang, L., Wang, J., Hao, Y., \& Hua, F. (2011). Research on e-Government evaluation model based on the principal component analysis. Information Technology and Management, 12(2), 173-185. https://doi.org/10.1007/s10799-011-0083-8

Shareef, M. A., Archer, N., \& Dwivedi, Y. K. (2015). An empirical investigation of electronic government service quality: from the demand-side stakeholder perspective. Total Quality Management \& Business Excellence, 26(3-4), 339-354. https://doi.org/10.1080/14783363.2013.832477

Shareef, M. A., Kumar, V., Kumar, U., \& Dwivedi, Y. K. (2011). E-Government Adoption Model (GAM): Differing service maturity levels. Government Information Quarterly, 28(1), 1735. https://doi.org/10.1016/j.giq.2010.05.006

Stefanovic, D., Marjanovic, U., Delić, M., Culibrk, D., \& Lalic, B. (2016). Assessing the success of e-government systems: An employee perspective. Information \& Management, 53(6), 717-726. https://doi.org/10.1016/j.im.2016.02.007

Teo, T., Srivastava, S., \& Jiang, L. (2008). Trust and Electronic Government Success: An Empirical Study. Journal of Management Information Systems, 25, 99-132. 
https://doi.org/10.2753/MIS0742-1222250303

United Nations. (2016). UN E-Government Survey 2016: e-government in support of sustainable development.

Valaei, N., \& Baroto, M. B. (2017). Modelling continuance intention of citizens in government Facebook page: A complementary PLS approach. Computers in Human Behavior, 73, 224-237. https://doi.org/10.1016/j.chb.2017.03.047

Veeramootoo, N., Nunkoo, R., \& Dwivedi, Y. K. (2018). What determines success of an egovernment service? Validation of an integrative model of e-filing continuance usage. Government Information Quarterly, 35(2), 161-174. https://doi.org/10.1016/j.giq.2018.03.004

Venkatesh, V., Morris, M. G., Davis, G. B., \& Davis, F. D. (2003). User Acceptance of Information Technology: Toward a Unified View. MIS Quarterly, 27(3), 425-478. Retrieved from http://www.jstor.org/stable/30036540

Venkatesh, V., Sykes, T. A., \& Venkatraman, S. (2014). Understanding e-Government portal use in rural India: Role of demographic and personality characteristics. Information Systems Journal, 24(3), 249-269. https://doi.org/10.1111/isj.12008

Venkatesh, V., Thong, J. Y. L., Chan, F. K. Y., Hu, P. J. H., \& Brown, S. A. (2011). Extending the two-stage information systems continuance model: Incorporating UTAUT predictors and the role of context. Information Systems Journal, 21(6), 527-555. https://doi.org/10.1111/j.1365-2575.2011.00373.x

Voorhees, C. M., Brady, M. K., Calantone, R., \& Ramirez, E. (2016). Discriminant validity testing in marketing: an analysis, causes for concern, and proposed remedies. Journal of the Academy of Marketing Science, 44(1), 119-134. https://doi.org/10.1007/s11747015-0455-4

Wang, C. (2014). Antecedents and consequences of perceived value in Mobile Government continuance use: An empirical research in China. Computers in Human Behavior, 34, 140-147. https://doi.org/10.1016/j.chb.2014.01.034

Wang, W. T., Wang, Y. S., \& Liu, E. R. (2015). The stickiness intention of group-buying websites: The integration of the commitment-trust theory and e-commerce success model. Information and Management, 53(5), 625-642. 
https://doi.org/10.1016/j.im.2016.01.006

Wang, Y.-S., \& Liao, Y.-W. (2008). Assessing eGovernment systems success: A validation of the DeLone and McLean model of information systems success. Government Information Quarterly, 25(4), 717-733. https://doi.org/10.1016/j.giq.2007.06.002

Wang, Y. S. (2002). The adoption of electronic tax filing systems: An empirical study. Government Information Quarterly, 20(4), 333-352. https://doi.org/10.1016/j.giq.2003.08.005

Weerakkody, V., El-Haddadeh, R., \& Al-Shafi, S. (2011). Exploring the complexities of egovernment implementation and diffusion in a developing country: Some lessons from the State of Qatar. Journal of Enterprise Information Management, 24(2), 172-196. https://doi.org/10.1108/17410391111106293

Wu, I.-L., \& Chen, J.-L. (2005). An extension of Trust and TAM model with TPB in the initial adoption of on-line tax: An empirical study. International Journal of Human-Computer Studies, 62(6), 784-808. https://doi.org/10.1016/J.IJHCS.2005.03.003

Yang, H.-L., \& Lin, S.-L. (2015). User continuance intention to use cloud storage service. $\begin{array}{llll}\text { Computers in Human } & \text { Behavior, 219-232. }\end{array}$ https://doi.org/10.1016/j.chb.2015.05.057

Zhou, Z., Jin, X.-L., \& Fang, Y. (2014). Moderating role of gender in the relationships between perceived benefits and satisfaction in social virtual world continuance. Decision Support Systems, 65, 69-79. https://doi.org/10.1016/j.dss.2014.05.004 